\title{
Chapter 2 \\ The Potato and Its Contribution to the Human Diet and Health
}

\author{
Gabriela Burgos, Thomas Zum Felde, Christelle Andre, and Stan Kubow
}

\begin{abstract}
Potato has contributed to human diet for thousands of years, first in the Andes of South America and then in the rest of the world. Its contribution to the human diet is affected by cooking, potato intake levels, and the bioavailability of potato nutrients. Generally, the key nutrients found in potatoes including minerals, proteins, and dietary fiber are well retained after cooking. Vitamins $\mathrm{C}$ and $\mathrm{B}_{6}$ are significantly reduced after cooking while carotenoids and anthocyanins show high recoveries after cooking due to an improved release of these antioxidants.

In many developed countries potatoes are consumed as a vegetable with intakes that vary from 50 to $150 \mathrm{~g}$ per day for adults. On the other hand, in some rural areas of Africa and in the highlands of Latin American countries, potato is considered a staple crop and is consumed in large quantities with intakes that vary from 300 to $800 \mathrm{~g}$ per day for adults. These marked differences in the potato intake affect significantly the contribution of potato nutrients to the human dietary requirements.

In recent years, information about nutrient bioaccessibility and bioavailability from potatoes has become available indicating higher bioaccessibility of minerals and vitamins in potato as compared with other staple crops such as beans or wheat. Bioavailability refers to the fraction of an ingested nutrient that is available for utilization in normal physiological functions and/or for body storage while bioaccessibility refers to the amount that is potentially absorbable from the gut lumen.

In addition, potatoes have shown promising health-promoting properties in human cell culture, experimental animal and human clinical studies, including anticancer, hypocholesterolemic, anti-inflammatory, anti-obesity, and antidiabetic
\end{abstract}

\footnotetext{
G. Burgos $(\bowtie) \cdot$ T. Zum Felde

International Potato Center, Lima, Peru

e-mail: g.burgos@cgiar.org; t.zumfelde@cgiar.org

C. Andre
}

The New Zealand Institute for Plant and Food Research Limited/Luxembourg Institute of Science and Technology, Auckland, New Zealand

e-mail: christelle.andre@ plantandfood.co.nz

S. Kubow

McGill University, Quebec, Canada

e-mail: stan.kubow@mcgill.ca 
properties with phenolics, anthocyanins, fiber, resistant starch, carotenoids as well as glycoalkaloids contributing to the health benefits of potatoes.

\subsection{Introduction}

Diverse studies have demonstrated that potato is an important source of carbohydrates, resistant starch, quality proteins, vitamins $\mathrm{C}$ and $\mathrm{B}_{6}$ as well as potassium (Camire et al. 2009). Potato is also a source of antioxidants that can contribute to prevent both degenerative and age-related diseases with lutein and zeaxanthin being present in high levels in yellow-fleshed potatoes (Burgos et al. 2009) and anthocyanins being present in purple and red-fleshed potato landraces (Burgos et al. 2013b) commonly grown and eaten in the Andean highlands of Peru, Bolivia, Ecuador, and Colombia. Potatoes also contain glycoalkaloids, which in high concentrations can be toxic to humans but in low concentrations can have beneficial effects such as inhibition of the growth of cancer cells (Friedman 2015). The nutritional composition of potatoes is summarized in Fig. 2.1. The concentration of energy, starch, protein, lipids, dietary fiber, potassium, phosphorus, magnesium, iron, zinc, vitamin $\mathrm{C}$, vitamin $\mathrm{B}_{6}$, chlorogenic acid, and glycoalkaloids has a range of variation independent from the flesh color. Yellow-fleshed potatoes have a carotenoid concentration higher than white-fleshed potatoes while purple potatoes have a higher anthocyanin concentration than red- or white-fleshed potatoes.

Like other plant foods, the nutritional composition of potatoes is affected by different pre-harvest (environment, cultural practices, maturity at harvest, biotic and abiotic stresses, etc.) and post-harvest (processing, storage, transport, etc.) conditions.

Potato has contributed to the human diet for thousands of years, first in the Andean region and then in the rest of the world. Its contribution is affected by cooking, the amount of potato intake, and the bioavailability of the nutrients. Generally, the key phytonutrients found in potatoes including minerals, proteins, and dietary fibers are well retained after cooking. Vitamins $C$ and $B_{6}$ are significantly reduced after cooking while carotenoids and anthocyanins show high recovery after cooking due to an improved release of these antioxidants from the food matrix after cooking (Tian et al. 2016). In this chapter, the range of nutrient concentrations is expressed on a fresh weight (FW) basis and ranges refer to both raw and cooked potatoes. However, for calculating their contribution to the diet, only values of cooked potatoes are considered.

The worldwide mean potato intake is equivalent to $93 \mathrm{~g}$ per day (FAO 2013). However, this value has a large range of variation. In many developed countries potatoes are consumed as a vegetable and served as a part of a larger meal with intakes that vary from 50 to $150 \mathrm{~g}$ per day for adults. On the other hand, in some rural areas of Africa and in the highlands of Latin American countries, potato is considered a staple crop and consumed alone in large quantities as a complete meal with intakes that vary from 300 to $800 \mathrm{~g}$ per day for adults (De Haan et al. 2019). 


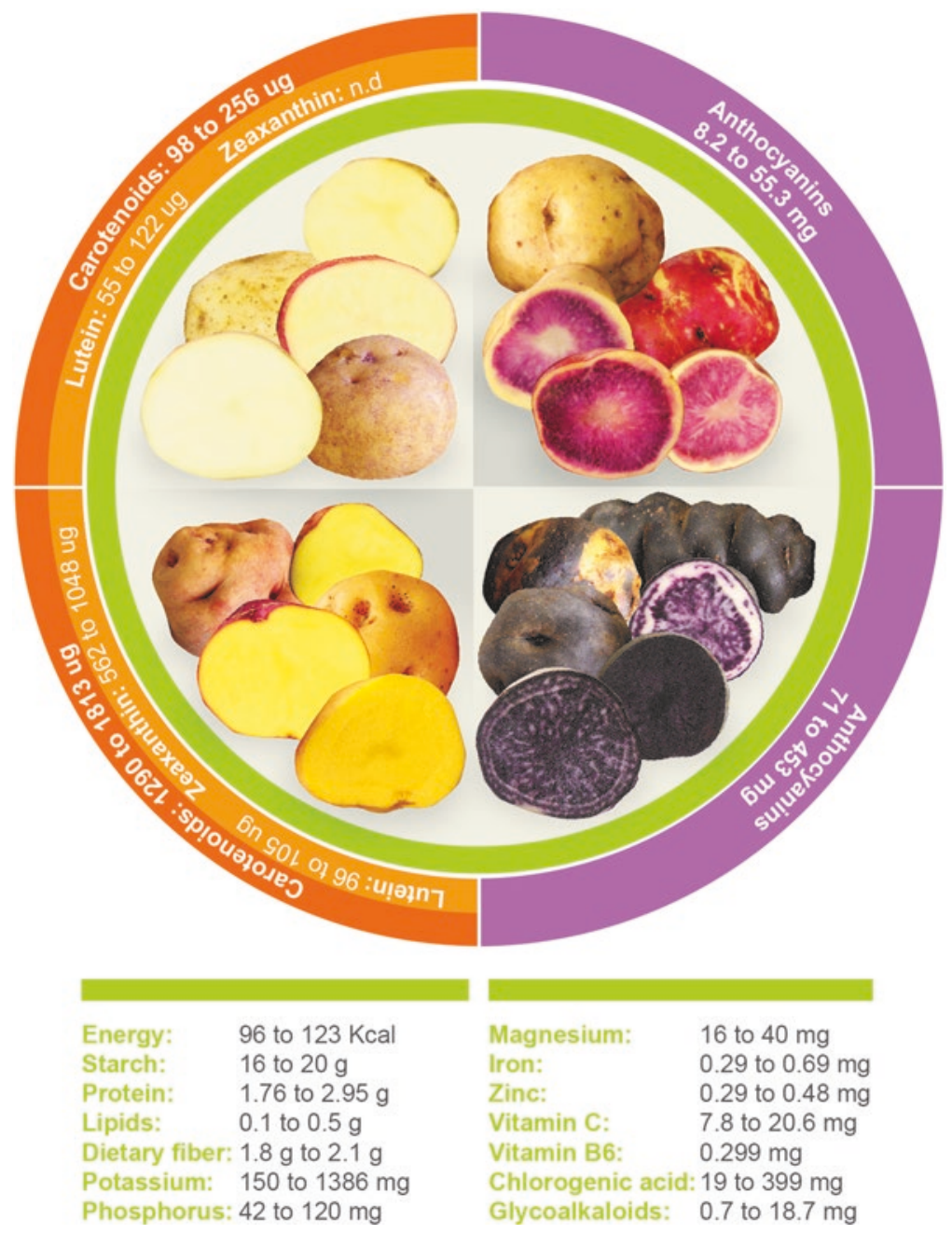

Fig. 2.1 Nutritional composition of potatoes per $100 \mathrm{~g} \mathrm{FW}$

Implications of the contribution of potatoes to the human diet as related to the magnitude of potato intake are also described in this chapter.

Bioavailability refers to the fraction of an ingested nutrient that is available for utilization in normal physiological functions and/or for its contribution towards body stores (La Frano et al. 2014). Many factors affect the bioavailability of a compound; these may be divided into exogenous factors such as the complexity of the food matrix, the chemical form of the compound of interest, structure and amount of co-ingested compounds as well as endogenous factors including mucosal mass, intestinal transit time, rate of gastric emptying, intestinal and hepatic metabolism, and the extent of conjugation and protein-binding in blood and tissues (Holst and 
Williamson 2008). A prerequisite for bioavailability of any compound is its bioaccessibility in the gut, defined as the amount that is potentially absorbable from the lumen (Fernández-Garcia et al. 2009). Bioavailability can be limited by a low bioaccessibility, which can be affected by the nature of the food matrix, location within the plant, food processing, gastric and luminal digestion, in addition to the physicochemical properties of the compound itself. In this chapter, the bioaccessibility and bioavailability of phytonutrients in potato will be reported and discussed.

The contribution of potato to human health will be described in terms of the evidence concerning the anticancer, hypocholesterolemic, anti-inflammatory, antiobesity, and anti-diabetic role of potatoes.

\subsection{Contribution to Diet}

\subsubsection{Energy}

The energy provided by $100 \mathrm{~g}$ of boiled tubers of potatoes varies from 96.33 to $123.17 \mathrm{kcal}$ (De Haan et al. 2019), which is similar to the energy provided by $100 \mathrm{~g}$ of cooked rice $(130 \mathrm{kcal})$ but lower than the energy provided by $100 \mathrm{~g}$ of wheat (361 kcal), $100 \mathrm{~g}$ of cooked cassava (160 kcal) and soybeans (173 kcal) (King and Slavin 2013). Potato has a low energy density with $100 \mathrm{~g}$ of boiled potatoes contributing between 4 and $6 \%$ of the requirement of energy of an adult of between 50 and $90 \mathrm{~kg}$ of weight (considering 1.90 as basal metabolic rate factor, FAO/OMS/UNU 2004). However, preparing and serving potatoes with ingredients with a high fat content raises greatly the caloric value of the dish. One hundred grams of potato chips and French fries provide 529 and 564 kcal, respectively.

In areas where potato is considered as a staple food, the amount of potato intake is high and consequently the contribution of potatoes towards meeting dietary requirements is much higher. In Huancavelica, a location in the Peruvian central highlands, women have an average daily consumption of 840 and $645 \mathrm{~g}$ during abundance and scarcity period of potato, respectively. In those regions, potatoes are mainly eaten as boiled and provide between 28 and $38 \%$ of the recommended total energy requirements for women (De Haan et al. 2019).

\subsubsection{Carbohydrates}

\subsubsection{Starch}

Starch is the predominating carbohydrate in potato ranging from 16.5 to $20.0 \mathrm{~g} / 100 \mathrm{~g}$ FW (Liu et al. 2007). Biochemically, potato starch is composed of amylose and amylopectin with the latter molecule typically making up 70-80\% of the available starch in the tuber and the remaining portion being composed of amy- 
lose (Zeeman et al. 2010). Starch can also be classified by levels of digestibility within the human intestinal tract, i.e. rapidly digested (RDS), slowly digested (SDS), or resistant (RS) starch (Englyst et al. 1992). RDS and SDS represent the portion of starch digested within the first 20 and 21-120 min post-ingestion, respectively. The remaining resistant starch (RS) is undigested and fermented when it reaches the large intestine with the production of short-chain fatty acids (Raigond et al. 2014). Because of the resistance of the amylose structure to digestion, more of the RS component is expected to be composed of amylose rather than amylopectin. The rapid breakdown of amylopectin to digestion is the reason that it is more prevalent in RDS and SDS fractions (Bach et al. 2013). Potential health benefits attributed to SDS include satiety, improved physical performance, glucose tolerance enhancement and blood lipid level reduction in healthy individuals and in those with hyperlipidemia (Miao et al. 2015). Possible health benefits of RS include prevention of colon cancer, hypoglycemic effects, substrate provision for growth of gut probiotic microorganisms, reduction of gall stone formation, hypocholesterolemic effects, inhibition of fat accumulation, and increased absorption of minerals (Sajilata et al. 2006).

Monro et al. (2009) determined the RDS, SDS, and RS concentration of freshly cooked potatoes from nine potato varieties and found concentrations ranging from 9 to $15 \mathrm{~g} / 100 \mathrm{~g} \mathrm{FW}$, from 0 to $1.72 \mathrm{~g} / 100 \mathrm{~g} \mathrm{FW}$, and from 0.58 to $1.05 \mathrm{~g} / 100 \mathrm{~g} \mathrm{FW}$, respectively. These authors also found that cooking and then cooling potatoes significantly increased SDS and RS (up to $7.7 \mathrm{~g}$ and $1.96 \mathrm{~g} / 100 \mathrm{~g}$ FW, respectively), while RDS was significantly reduced to $7.3 \mathrm{~g} / 100 \mathrm{~g}$ FW. This latter phenomenon is referred to as starch retrogradation, which is based upon rearrangement of the molecules of amylose and amylopectin causing decreased starch digestion (Leeman et al. 2005).

Glycemic index (GI) is a measure of the extent of the change in blood glucose content (glycemic response) following consumption of digestible carbohydrate, relative to a standard such as glucose (Venn and Green 2007). A higher GI value represents a more rapid entry of a larger quantity of glucose from a test food into the bloodstream. Based on in vivo postprandial GI, high RDS content in foods has been significantly correlated with a high glycemic index response (Champ 2004), whereas low RDS levels are associated with low to medium GI values (Lynch et al. 2007). A wide variability in GI values of potatoes has been noted ranging from high to medium to low values based on cultivar differences (Ek et al. 2012). Such variations could partly be related to differences in the amylopectin to amylose ratio as amyloserich starches are digested more slowly due to their difficulty to gelatinize and swell as opposed to starches with a high amylopectin content (Brennan 2005). Bach et al. (2013) defined low RDS and high SDS as the optimal profile for potatoes that leads to low GI values, and identified two genotypes with this profile. Tuber cooking followed by cooling (forming retrograded starch) is also another way for the consumer to obtain lower postprandial glucose levels, and thereby benefit from reduced GI following potato intake (Fernandes et al. 2005). Lowering the dietary GI load has been associated with body weight loss, improved blood pressure, and decreased risk of cardiovascular diseases, whereas habitual intake of high GI foods has been linked 
to type 2 diabetes and other chronic heart issues (McGill et al. 2013). As the GI does not take into account the typical portion size, the GI value and the quantity of carbohydrates are combined to generate the glycemic load (GL) value, which can better quantify the glycemic impact of a food (Salmeron et al. 1997). Initial studies involving potatoes were limited by the sole use of GI for their glycemic evaluation (Crapo et al. 1977; Soh and Brand-Miller 1999), which categorized them with a high GI. In contrast, potatoes have been generally noted to have a medium to low glycemic impact based on the GL estimation (Lynch et al. 2007).

\subsubsection{Sugars}

Potato tubers also contain significant quantities of free sugars with glucose and fructose as the principal monosaccharides and sucrose as the major disaccharide. Glucose, fructose, and sucrose concentrations in raw tubers of tetraploid potatoes range from 3.25 to $255 \mathrm{mg} / 100 \mathrm{~g} \mathrm{FW}$, from 2.5 to $153.7 \mathrm{mg} / 100 \mathrm{~g} \mathrm{FW}$, and from 43 to $159.7 \mathrm{mg} / 100 \mathrm{~g} \mathrm{FW}$, respectively (Amrein et al. 2003; Rodríguez et al. 2010). Higher levels of glucose, fructose, and sucrose have been recently reported for diploid potato group Phureja with concentrations ranging from 11.5 to $701 \mathrm{mg} / 100 \mathrm{~g}$ FW for glucose, from 7.25 to $605 \mathrm{mg} / 100 \mathrm{~g} \mathrm{FW}$ for fructose and from 159 to $737 \mathrm{mg} / 100 \mathrm{~g}$ FW for sucrose (Duarte-Delgado et al. 2016). The reducing sugars glucose and fructose as well as free asparagine are acrylamide precursors. Acrylamide is formed through the Maillard reaction during high temperature cooking such as frying, roasting, or baking (Muttucumaru et al. 2008). Acrylamide has been classified as "probably carcinogenic to humans" by the WHO and the International Agency for Research on Cancer. Therefore, the reducing sugar content in potatoes has been recommended not to be greater than $100 \mathrm{mg} / 100 \mathrm{~g} \mathrm{FW}$ in order to keep acrylamide formation on a low level (Kumar et al. 2004). Importantly, cold storage $\left(2-4{ }^{\circ} \mathrm{C}\right)$ may induce an accumulation of reducing sugars in tuber tissue leading to undesirable browning, production of bitter flavors, and increased levels of acrylamide with cooking (Neilson et al. 2017).

\subsubsection{Protein}

According to Camire et al. (2009), the protein content of potatoes generally ranges from 1 to $1.5 \mathrm{~g} / 100 \mathrm{~g}$ FW depending on the cultivar. De Haan et al. (2019) reported higher levels of protein in cooked tubers of Peruvian floury landraces (1.76-2.95 g/100 g FW). Potato protein content is generally low compared with other major staples like maize and beans although potato yields more protein per unit growing area than do cereals (Bamberg and Del Rio 2005). Also, the quality of the potato protein, which reflects its digestibility and indispensable amino acid content, is very good. The biological value of potato protein - the proportion retained for growth or maintenance divided by the amount absorbed-is high. Depending on 
the cultivar, the biological value of potato protein is between 90 and 100 and is very similar to the biological value of whole egg protein (100) and is higher than that of soybeans (84) and legumes (73) (Camire et al. 2009).

The levels of lysine, methionine, threonine, and tryptophan are likely to limit the protein quality of mixed diets consumed by humans. Potatoes exceed the recommended levels of these indispensable amino acids, demonstrating that potato protein is of high quality. Compared with pasta, white rice, and whole grain cornmeal, potatoes are the only staple food meeting the recommended lysine level. However, sulfur-containing amino acids (methionine + cysteine) are lower in potatoes than in the other common plant staple foods (King and Slavin 2013).

\subsubsection{Lipids}

Total lipids of potatoes are low and range from 0.1 to $0.5 \mathrm{~g} / 100 \mathrm{~g}$ FW and consist mainly of phospholipids (47\%), glycol and galactolipids (22\%), which are structural elements of biological membranes as well as neutral lipids (21\%) such as acylglycerols and free fatty acids (Ramadan and Oraby 2016). More than 94\% of the tuber lipids contain esterified fatty acids. The essential polyunsaturated fatty acids with one to three double bounds consist of mainly linoleic acid (C18:2 cis-9,12, an $n-6$ fatty acid) and linolenic acid (C18:3 cis-9,12,15, an $n-3$ fatty acid) (70-75\%), precursors of a wide range of bioactive compounds generated endogenously (Galliard 1973). The composition of the fatty acids of the potato lipids is nutritionally advantageous. For example, potato consumption in the United Kingdom was estimated to provide 10 and $13 \%$ of the dietary $n-6$ and $n-3$ polyunsaturated fatty acid intake, respectively (Gibson and Kurilich 2013). In contrast, potato intake provided only $4 \%$ of saturated fatty acid and $6 \%$ trans fatty acid intake, which was largely attributed to the addition of fats and oils such as butter and margarine to potato dishes.

\subsubsection{Fiber}

Dietary fiber represents the undigested and unabsorbed carbohydrate part in the diet. These resistant carbohydrates may be fermented in the large intestine. Soluble fibers lower serum lipids, whereas insoluble fibers increase stool weight (Slavin 2008). Potatoes contain dietary fiber in their cell walls, especially in the thickened cell walls of the peel (Camire et al. 2009). Cooked potatoes without the skin provide $1.8 \mathrm{~g}$ fiber $/ 100 \mathrm{~g}, \mathrm{FW}$, whereas cooked potatoes with the skin provide $2.1 \mathrm{~g}$ fiber/100 g FW. Potatoes contain less fiber than whole-grain cornmeal $(7.3 \mathrm{~g} / 100 \mathrm{~g})$, but more fiber than white rice $(0.3 \mathrm{~g} / 100 \mathrm{~g})$ or whole-wheat cereal $(1.6 \mathrm{~g} / 100 \mathrm{~g})$. Although potatoes cannot therefore be considered a high-fiber food, they can be a significant source of fiber for individuals regularly eating potatoes, particularly in 
developed countries where fiber intake is generally far below recommended levels (Auestad et al. 2015). In that regard, potatoes have been indicated to contribute 14.4-26.2\% of daily fiber intake in men and women living in the USA based on the National Health and Nutrition Examination Survey (NHANES) data (2009-2010).

\subsubsection{Minerals}

Potassium is the most abundant mineral in potato with concentrations varying from 150 to $1386 \mathrm{mg} / 100 \mathrm{~g} \mathrm{FW}$ (Nassar et al. 2012). Potassium functions as an important electrolyte in the nervous system. High intake levels of potassium can help control high blood pressure and may decrease the risk of stroke (Bethke and Jansky 2018). One hundred grams of boiled potatoes can contribute up to $16 \%$ of the Adequate Intake (AI) of potassium recommended for adults (4700 $\mathrm{mg}$ per day).

Phosphorus and magnesium are also present in potato in moderate quantities ranging from 42 to $120 \mathrm{mg} / 100 \mathrm{~g} \mathrm{FW}$ and from 16 to $40 \mathrm{mg} / 100 \mathrm{~g} \mathrm{FW}$, respectively (Bonierbale et al. 2010). One hundred grams of boiled potatoes can contribute up to $11 \%$ of the Estimated Average Requirement (EAR) of phosphorus and magnesium for adults (42-120 and 265-340 mg per day, respectively). Calcium is present in minor quantities in potato ranging from 2 to $20 \mathrm{mg} / 100 \mathrm{~g} \mathrm{FW}$; contributing no more of $2 \%$ of the EAR of calcium for adults (800-1100 mg per day).

Iron and zinc concentrations from raw potatoes range from 0.25 to $0.83 \mathrm{mg} / 100 \mathrm{~g}$ FW and from 0.23 to $0.39 \mathrm{mg} / 100 \mathrm{~g} \mathrm{FW}$, respectively (Burgos et al. 2007). Iron and zinc concentrations are significantly affected by the growing environment. Interestingly, Lombardo et al. (2013) reported that soil composition affects the mineral concentration of crops, with a sandy texture of the soil favoring the iron oxidation processes to insoluble polymers and consequently reducing iron availability to the plant.

Burgos et al. (2007) reported iron and zinc concentration in cooked potatoes ranging from 0.29 to $0.69 \mathrm{mg} / 100 \mathrm{~g} \mathrm{FW}$ and from 0.29 to $0.48 \mathrm{mg} / 100 \mathrm{~g} \mathrm{FW}$, respectively. These values are lower than iron and zinc concentrations reported for cereals and legumes but bioavailability of iron and zinc from potatoes may be higher due to the presence of high levels of ascorbic acid-which facilitates iron absorption in the human body - and low levels of phytic acid, an inhibitor of iron and zinc absorption. It has been recently demonstrated that the bioaccessibility of iron in potato is higher than that reported in crops such as wheat and beans. Approximately $63-79 \%$ of the potato iron is released from the food matrix after in vitro gastrointestinal digestion, and therefore available for intestinal absorption (Andre et al. 2015).

In the Andean highlands, where there is little access to meat and the levels of anemia and malnutrition are high, potatoes are an important dietary source of iron due to their high consumption. For example, in Huancavelica, in the Peruvian highlands, women and children consume on average 840 and $200 \mathrm{~g}$ of potato per day, respectively (De Haan et al. 2019). Similarly, in parts of Rwanda and other African countries, women consume an average of $400 \mathrm{~g}$ of potatoes per day. Therefore, 
improving the iron and zinc concentrations of potato and their bioavailability would have a real impact to contribute to reduce malnutrition and improve life quality in these and other areas where anemia and/or stunted growth are still pervasive.

The International Potato Center (CIP) has been working for the past 15 years on potato mineral biofortification to increase the concentration of iron and zinc in this crop. The CIP Biofortification Potato Program started from a baseline of 0.48 $\mathrm{mg} / 100 \mathrm{~g} \mathrm{FW}$ for iron and $0.35 \mathrm{mg} / 100 \mathrm{~g} \mathrm{FW}$ for zinc. After three cycles of breeding and recurrent selection, concentrations of the first biofortified potatoes reach $0.73 \mathrm{mg}$ iron and $0.63 \mathrm{mg}$ zinc $/ 100 \mathrm{~g}$ FW. Considering $400 \mathrm{~g}$ of potato consumption for women of the Andes, the consumption of biofortified potatoes would cover 41 and $37 \%$ of the EAR of iron and zinc in women.

Presently, CIP is combining the first products of its biofortification breeding program with advanced breeding lines to release new varieties that will be able to withstand major potato pests and diseases, tolerate heat and drought, providing high yields, and respond to preferences of farmers and consumers.

\subsubsection{Vitamins}

Potatoes are a good source of ascorbic acid (vitamin C) and pyridoxine (vitamin $\mathrm{B}_{6}$ ). Vitamin $\mathrm{C}$ as an antioxidant plays an important role in protection against oxidative stress. Vitamin $\mathrm{C}$ is an important free radical scavenger of reactive oxygen species such as hydroxyl radicals, superoxide anions, singlet oxygen, and hydrogen peroxide that can cause tissue damage resulting from lipid peroxidation, DNA breakage or base alterations, which may contribute to degenerative diseases such as heart disease or cancer (Bates 1997). In addition, due to its participation in the oxidation of transition metal ions, vitamin $\mathrm{C}$ also plays an important role in enhancing the bioavailability of non-haem iron (Teucher et al. 2004) and serves as a cofactor in the synthesis of collagen needed to support cardiovascular function, maintenance of cartilage, bones, and teeth, as well as wound healing (Naidu 2003).

Fresh potatoes have varying concentrations of vitamin $\mathrm{C}$, which can reach $50 \mathrm{mg} / 100 \mathrm{~g} \mathrm{FW}$ (Han et al. 2004) when they are freshly harvested. Significant variation in vitamin $\mathrm{C}$ concentrations of potatoes occur due to genotype and environment and genotype by environment interactions (Andre et al. 2007; Burgos et al. 2009).

Cooking and storage reduce the concentration of vitamin $\mathrm{C}$ in potato tubers. In addition, there are differences in the degree of reduction of vitamin $\mathrm{C}$ content depending on the cooking types. Retention levels of vitamin $\mathrm{C}$ after boiling in 20 native landraces varied between 50 and $90 \%$. The losses may be caused by: (1) leaching into cooking water, (2) destruction by heat treatment, and (3) oxidation. It is interesting to note that the peel forms a barrier preventing loss of nutrients during cooking. As a consequence, boiling potato when it is peeled results in $10 \%$ more loss of vitamin C or phenolic compounds than if it is cooked with the peel (Woolfe and Poats 1987). Retention levels after storing under farming conditions has been 
shown to vary between 22 and 62\%, depending on the variety (Burgos et al. 2009). Retention levels of vitamin C in 12 genotypes grown in Colorado state in the USA after 7 months of cold storage was less than 50\% (Külen et al. 2012).

One hundred grams of cooked potatoes with vitamin C levels around $20 \mathrm{mg} / 100 \mathrm{~g}$ FW can provide between 27 and 33\% of the EAR of vitamin C for an adult (75 for males and 60 for females, according to FAO/WHO 2001). One hundred grams of cooked potatoes contains lower concentrations of vitamin $\mathrm{C}$ than $100 \mathrm{~g}$ of cooked broccoli (68-108 mg/100 g FW; depending on the way of cooking; Yuan et al. 2009), $100 \mathrm{~g}$ of cooked spinach (44-79 mg/100 g FW; depending on the way of cooking; Zeng 2013) and $100 \mathrm{~g}$ of raw red pepper (up to $200 \mathrm{mg} / 100 \mathrm{~g}$; Wahyuni et al. 2011). However, it is noteworthy that the final contribution of a particular food to the total intake of vitamin $\mathrm{C}$ depends on the total amount consumed in the diet and so potatoes may therefore contribute to a significant extent to the total dietary intake of vitamin C (Love and Pavek 2008). In that respect, potatoes have been estimated to provide over $50 \%$ of the daily vitamin $\mathrm{C}$ requirement in the USA and approximately $20 \%$ of the dietary vitamin C intake in Europe (Love and Pavek 2008).

Vitamin $\mathrm{B}_{6}$, also called pyridoxine, is a versatile cofactor for key metabolic processes (Hellmann and Mooney 2010) that plays a major role in various cellular reactions and also confers several health benefits for humans, which may be partly attributed to its antioxidant capabilities (Fitzpatrick et al. 2012). It helps in maintaining normal nerve function and plays a crucial role in the synthesis of neurotransmitters such as dopamine and serotonin. Vitamin $\mathrm{B}_{6}$ also assists normal nerve cell communication and acts as a coenzyme in the breakdown and utilization of carbohydrates, fats and proteins. In plant, it is a potent antioxidant, critical for plant pathogen resistance (Spinneker et al. 2007).

Potatoes are considered to be a good dietary source of vitamin $\mathrm{B}_{6}$, with concentrations ranging from $0.450 \mathrm{mg} / 100 \mathrm{~g} \mathrm{FW}$ to $0.675 \mathrm{mg} / 100 \mathrm{~g} \mathrm{FW}$ (Moonney et al. 2013). Physical and chemical factors such as heat, light exposure, and $\mathrm{pH}$ also influence vitamin $\mathrm{B}_{6}$ content, but this vitamin is relatively stable during storage (Fitzpatrick et al. 2012).

The mean concentration of vitamin $\mathrm{B}_{6}$ in cooked potatoes $(0.299 \mathrm{mg} / 100 \mathrm{~g} \mathrm{FW})$ is higher than the mean concentration of other staple crops such as maize $(0.139 \mathrm{mg} / 100 \mathrm{~g} \mathrm{FW})$, rice $(0.050 \mathrm{mg} / 100 \mathrm{~g} \mathrm{FW})$, cassava $(0.051 \mathrm{mg} / 100 \mathrm{~g} \mathrm{FW})$, and wheat ( $0.034 \mathrm{mg} / 100 \mathrm{~g} \mathrm{FW}$ ) (Fudge et al. 2017). One hundred grams of cooked potatoes can provide between 17 and $23 \%$ of the Recommended Dietary Allowance (RDA) of $\mathrm{B}_{6}$ from an adult (1.3-1.7 $\mathrm{mg}$ per day).

Potato tuber contains also moderate amount of vitamin E (Chitchumroonchokchai et al. 2017). Vitamin $E$ is the collective name for a set of eight related tocopherols and tocotrienols, characterized by a hydrophobic isoprenoid tail and a more hydrophilic chromanol head (Bramley et al. 2000). In potato, significant amount of $\alpha$-tocopherol has been found in raw tubers of Andean genotypes, ranging from 68 to $517.5 \mu \mathrm{g} / 100 \mathrm{~g} \mathrm{FW}$ (recalculated from Andre et al. 2007), whereas amounts in commercial varieties varied between 15 and $75 \mu \mathrm{g} / 100 \mathrm{~g} \mathrm{FW}$ (recalculated from Andre et al. 2007 and Chun et al. 2006). 
In humans, as in plants, vitamin $\mathrm{E}$ is located primarily within the phospholipid bilayer of cell membranes. It reacts with and quenches free radicals in cell membranes, preventing polyunsaturated fatty acids from damage by lipid oxidation. Vitamin E deficiency has been associated with an elevated risk of artherosclerosis and other degenerative diseases. It is generally assumed that increases of $\alpha$-tocopherol in the diet may contribute to a decreased risk of chronic diseases (Andre et al. 2010). The EAR for vitamin $\mathrm{E}$ is of $15 \mathrm{mg}$ for women and men (Otten et al. 2010). The consumption of high vitamin $\mathrm{E}$ containing potato tubers, such as the Andean varieties, could therefore significantly increase the dietary vitamin E intake.

\subsubsection{Antioxidants}

Potato is one of the most important sources of antioxidants in the human diet (Lachman and Hamouz 2005). As such, it supports the antioxidant defense that reduces cellular and tissue toxicities that result from free radical-induced protein, lipid, carbohydrate, and DNA damage (Andre et al. 2010). In this way, potato antioxidants may reduce the risk for cancers, cardiovascular diseases, and type 2 diabetes.

Based on metabolic relationships and structural composition, there are three major groups of antioxidants present in potato, as in most plants. The first group consists in the aromatic phenolic compounds, which encompasses flavonoids including anthocyanins and flavonols produced by the flavonoid pathway, hydroxycinnamic acids and their derivatives produced by the phenylpropanoid pathway, and the amino acids tyrosine, phenylalanine, and tryptophan produced by the shikimate pathway. The second group encompasses the isoprenoid antioxidants such as the carotenoids and tocopherols; and the third group includes antioxidants related to ascorbate and glutathione functions in a redox system of compound-recycling that include ascorbic acid (Lovat et al. 2016).

\subsubsection{Phenolics}

Phenolic compounds, also known as polyphenols, constitute one of the most widely distributed group of dietary antioxidants in the plant kingdom, presenting more than 10,000 different structures, ranging from relatively simple phenols to complex polymers such as lignans and suberins. Phenolic compounds are produced in the cytoplasm and are subsequently transported in the vacuole or deposited in the cell wall. Routes to the major classes of phenolic compounds involve: (1) the core phenylpropanoid pathway from phenylalanine to an activated (hydroxy)cinnamic acid derivative, as well as specific branch pathways for the formation of (2) simple phenolic acids, lignins and lignans, (3) flavonoids, (4) tannins, and (5) stilbenes (Andre et al. 2009). Their aromatic cycles can be further modified through hydroxylations, 
methylations, glycosylations, acylations, or prenylations, extending their variability and complexity (Winkel-Shirley 2001). Phenolic acids include chlorogenic, caffeic, ferulic, and sinapic acids. Among flavonoids, anthocyanins are natural pigments, responsible for the red-blue color of many fruits and vegetables. Anthocyanins can also impact the organoleptic characteristics of foods, which may influence their technological behavior during food processing and also have implications in the field of human health (Pascual-Teresa and Sanchez-Ballesta 2008). Flavonols represent one of the most widespread flavonoid classes in plant and include compounds like quercetin and kaempferol that are most commonly found in their glycosylated form, i.e., linked with glucose or rutinose. As compared to other phenolic compounds, flavonol concentrations are known to be largely influenced by the environmental conditions during plant growth (Lancaster et al. 2000).

Phenolic compounds are considered to be health-promoting phytochemicals as they have shown in vitro antioxidant activity and have been reported to exhibit beneficial anti-bacterial, hypoglycemic, anti-viral, anti-carcinogenic, anti-inflammatory and vasodilatory properties (Duthie et al. 2000; Mattila and Hellstrom 2006).

\subsubsection{Chlorogenic Acid}

Chlorogenic acid has been reported as the predominant phenolic acid in raw and boiled potato tubers (Burgos et al. 2013b). The main function of chlorogenic acid in the plant appears to defend against pathogens. Concentrations of chlorogenic acid as well as other hydroxycinnamic acids are significantly induced following pathogen invasion, and deposited to enforce the cell walls to arrest pathogen development (Yogendra et al. 2015). In humans, these compounds consumed through diet are increasingly considered as effective protective agents against reactive oxygen species (ROS), which are known to be involved in aging and many degenerative diseases (Liang and Kitts 2015).

The isomers of chlorogenic acid, neo-chlorogenic acid, and crypto-chlorogenic acid, as well as caffeic acid are also found in potato tubers (Andre et al. 2007). Potatoes contain three isomers of chlorogenic acid depending on whether the hydroxycinnamate is attached to 3-, 4-, or 5-position of the quinic acid moiety with 5-O-caffeoylquinic acid as the principal chlorogenic acid. The 5-O-caffeoylquinic acid (CQA) isomer is also the principal chlorogenic acid component of coffee and apples (Stalmach et al. 2010; Clifford 1999). In vitro and ex vivo studies have demonstrated a reduction in oxidation of human LDL following the consumption of coffee suggesting that 5-O-CQA protects against in vitro oxidation of human LDL, a key step in the formation of atherosclerotic plaques (Natella et al. 2007; Richelle et al. 2001). 5-O-CQA has also been shown to exert anti-carcinogenic effects in animal models (Stalmach et al. 2010).

Lachman et al. (2013) have reported chlorogenic acid concentrations of raw potatoes ranging from 7.87 to $60.07 \mathrm{mg} / 100 \mathrm{~g} \mathrm{FW}$ in nonpeeled potatoes and from 5.11 to $46.13 \mathrm{mg} / 100 \mathrm{~g} \mathrm{FW}$ in their peeled counterparts, while Burgos et al. (2013b) report a wider range of variation in the chlorogenic acid concentration of raw purple 
potatoes (ranging from 63 to $329.75 \mathrm{mg} / 100 \mathrm{~g} \mathrm{FW}$ ). Boiling, baking, and microwaving reduce the chlorogenic acid concentration of potatoes with boiled tubers having a higher retention of chlorogenic acid than baked and microwaved ones (Lachman et al. 2013). In a recent study conducted by Piñeros-Niño et al. (2017), the chlorogenic acid concentration of cooked tubers from 193 potato varieties ranged from 19.25 to $399 \mathrm{mg} / 100 \mathrm{~g} \mathrm{FW}$. In a previous study by Burgos (2014), the chlorogenic acid concentration in cooked tubers of purple-fleshed cultivars ranged from 36.17 to $395.73 \mathrm{mg} / 100 \mathrm{~g} \mathrm{FW}$ and in red-fleshed cultivars from 14.45 to $48.60 \mathrm{mg} / 100 \mathrm{~g} \mathrm{FW}$.

The highest concentration of chlorogenic acid reported in $100 \mathrm{~g}$ of cooked potato tubers is similar to the maximum amount provided by a single cup of coffee $(350 \mathrm{mg}$ chlorogenic acid; Clifford 1999) and is tenfold higher than the maximum amount provided by whole apples (38.5 mg/100 g FW, Spanos and Wrolstad 1992).

Chlorogenic acid is only partially bioavailable and its bioactivity may be modulated by the gut microbiota that can generate bioactive secondary microbial phenolic metabolites such as caffeic acid that have much greater bioavailability (Tomas-Barberan et al. 2014; Olthof et al. 2003). Chlorogenic acid may also promote a healthy gut microbiome. In a batch culture fermentation model of the colon, chlorogenic acid was found to promote growth of Bifidobacterium bacterial species that could be beneficial for gut health (Mills et al. 2015).

\subsubsection{Anthocyanins}

Anthocyanins are a class of water-soluble flavonoids, which show a range of pharmacological effects, such as prevention of cardiovascular disease, obesity control, and anti-tumor activity. Their potential anti-tumor effects are reported to be based on a wide variety of biological activities including antioxidant, anti-inflammation, anti-mutagenesis, induction of differentiation, inhibiting proliferation by modulating signal transduction pathways, inducing cell cycle arrest, and stimulating apoptosis or autophagy of cancer cells; anti-invasion; anti-metastasis; reversing drug resistance of cancer cells and increasing their sensitivity to chemotherapy (Lin et al. 2017).

Anthocyanins are present in the flesh and skin of several purple- and red-fleshed potatoes such as those landraces found in the Andes, which show a wide range of anthocyanin structures and concentrations that are largely cultivar-dependent (Brown et al. 2003) and location-dependent (Ieri et al. 2011). Increased height above sea level, higher annual sum of precipitation, and lower annual average temperatures cause higher anthocyanin concentrations (Lachman et al. 2009).

The total anthocyanin concentration of raw and cooked purple-fleshed potatoes ranges from 63 to $588 \mathrm{mg} / 100 \mathrm{~g} \mathrm{FW}$ and from 71 to $453 \mathrm{mg} / 100 \mathrm{~g} \mathrm{FW}$, respectively (Burgos et al. 2013a, b). Total anthocyanin concentration of cooked red-fleshed potatoes ranges from 8.2 to $55.3 \mathrm{mg} / 100 \mathrm{~g} \mathrm{FW}$ (Burgos 2014).

Giusti et al. (2014) identified five major anthocyanidins (cyanidin, petunidin, pelargonidin, peonidin, and malvidin) in extract from purple potato and three major 
anthocyanidins (cyanidin, pelargonidin, and peonidin) in extracts of red potatoes. The extract of purple potatoes contained four major anthocyanins: cyanidin-3rutinoside-5-glucoside, petunidin-3-rutinoside-5-glucoside, pelargonidin-3rutinoside-5-glucoside, and peonidin-3-rutinoside-5-glucoside, with petunidin and peonidin glycosides being the most predominant. The extract of red-fleshed potatoes contained four major anthocyanins: cyanidin-3-rutinoside-5-glucoside, pelargonidin-3-rutinoside-5-glucoside, peonidin-3-rutinoside-5-glucoside, and pelargonidin-3-rutinoside, with pelargonidin-3-rutinoside-5-glucoside being the most predominant.

Burgos (2014) characterized the anthocyanin profile of 12 purple-fleshed accessions and 6 red-fleshed accession from CIP's genebank and found that in purplefleshed accessions the predominant anthocyanin is petunidin-3-(coumaroyl) rutinoside-5-glucoside (petanin), representing from 37 to $78 \%$ of the total anthocyanins. It is followed by peonidin-3-(coumaroyl) rutinoside-5-glucoside, cyanidin-3(coumaroyl) rutinoside-5-glucoside, and minor proportions of malvidin 3-(coumaroyl) rutinoside-5-glucoside and pelargonidin-3-(coumaroyl) rutinoside-5glucoside. In red-fleshed accessions, the predominant anthocyanin is pelargonidin-3(coumaryl) rutinoside-5-glucoside, representing 41-75\% of the total anthocyanins. It is followed by peonidin-3-(coumaroyl) rutinoside-5-glucoside, pelargonidin-3rutinoside, and cyanidin-3-(coumaroyl) rutinoside-5-glucoside in various proportions and then by pelargonidin-3-(coumaryl) rutinoside in minor proportions. Figure 2.2 shows as an example the anthocyanin profile for two purple-fleshed accessions (CIP 705534 and CIP 702363) and two red-fleshed accessions (CIP 703625 and CIP 702453). Pt3(c)R5G represented by the purple bar is dominant in the purple-fleshed accessions while $\mathrm{PI} 3 \mathrm{R}(\mathrm{c}) \mathrm{R} 5 \mathrm{G}$ represented by the pink bar is dominant in the red-fleshed potatoes.

CIP 705534

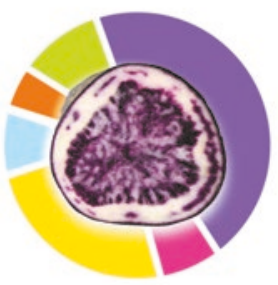

PI3R
CIP 702363

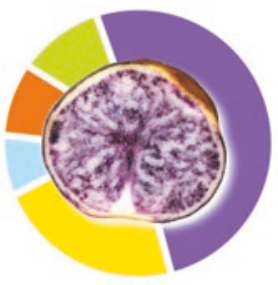

D3(c)R5G

Fig. 2.2 Anthocyanin profile in purple-fleshed and red-fleshed potatoes. (P13R: pelargonidin-3rutinoside, P13R(c)R5G: pelargonidin-3-(coumaroyl) rutinoside-5-glucoside, Pt3(c)R5G: petunidin-3-(coumaroyl) rutinoside-5-glucoside, Po3(c)R5G: peonidin-3-(coumaroyl) rutinoside5-glucoside, C3(c)R5G: cyanidin-3-(coumaroyl) rutinoside-5-glucoside, M3(c)R5G: malvidin 3-(coumaroyl) rutinoside-5-glucoside) 
The most prominent anthocyanins present in the red- and purple-fleshed accessions are acylated with hydroxycinnamic acid (Fossen and Andersen 2000). Three different cinnamic acids were found acylating the anthocyanins in the extract of purple and red potatoes: caffeic, $p$-coumaric and ferulic acid (Giusti et al. 2014). Acylated anthocyanins are known to be stable and hence can be considered as promising natural colorants for the food industry.

The highest anthocyanin concentration reported in a dark purple-fleshed potato (above $400 \mathrm{mg} / 100 \mathrm{~g} \mathrm{FW}$; Andre et al. 2007) is lower than in blueberries (558 mg/100 g, FW; Hosseinian and Bea 2007), cranberries (589 mg/100 g FW; Wada and Ou 2002), eggplant (750 mg/100 g FW; Wu et al. 2006), and purple corn (1642 mg/100 g FW; Cevallos-Casals and Cisneros Zevallos 2003). However, the contribution of purple-fleshed potatoes to the diet can be considerably higher considering the high mean intake of potatoes in some areas like the Andean highlands where consumption may reach $500 \mathrm{~g}$ per day, as compared to the mean intake of blueberries, cranberries, and eggplant (1 g per day in the United States; Wu et al. 2006).

Kubow et al. (2017) studied the biotransformation of anthocyanins from cooked purple-fleshed potatoes using a dynamic human gastrointestinal (GI) model that includes stomach, small intestine, and colonic vessels. After $24 \mathrm{~h}$ digestion, liquid chromatography-mass spectrometry identified 15-36 anthocyanin species throughout the GI vessels. Genetic background of the purple potato cultivars led to major variances in the pattern of anthocyanin breakdown and release during digestion composition. Diminished concentrations of several anthocyanin species in the colonic vessels indicated microbial biotransformation which is, in turn, associated to increased bioaccessibility.

The cytotoxicity and cell viability of colonic Caco- 2 cancer cells and nontumorigenic colonic CCD-112CoN cells after $24 \mathrm{~h}$ exposure to colonic fecal water of purple-fleshed potato digests has been also tested by Kubow et al. (2017). The cultivar Leona showed a significant potency to induce cytotoxicity and decrease viability of Caco-2 cells. The differing microbial anthocyanin metabolite profiles in colonic vessels between cultivars were indicated to play a significant role in the impact of fecal water toxicity on tumor and nontumorigenic cells.

In white- and yellow-fleshed potato tubers, flavonols predominate in the flavonoid profile (Andre et al. 2007). Flavonols have been extensively studied in the past 10 years as they present a range of putative health-promoting effects, including reduced risk of cancer and cardiovascular diseases (Wang et al. 2016). Rutin in particular has shown strong antioxidative and anti-inflammatory effects at the cellular level (Habtemariam and Lentini 2015).

In potato tubers, rutin (quercetin-3- $O$-rutinoside) and kaempferol-3- $O$-rutinoside are the most important compounds, with reported concentrations of $0-4.78 \mathrm{mg}$ and 0-5.68 mg/100 g FW, respectively, in Andean raw potato tubers (Andre et al. 2007). The influence of various cooking methods on potato flavonols has been investigated, which revealed the stability of the concentrations through treatment (Navarre et al. 2010). The bioaccessibility of these compounds was also high (close to $100 \%$ on average) when evaluated in a collection of 12 Andean potato genotypes (Andre et al. 2015). 


\subsubsection{Carotenoids}

Potatoes contain lipophilic phytonutrients in the form of carotenoids that have numerous health-promoting properties including decreasing risk of several chronic diseases (Gammone et al. 2015; Wu et al. 2015). Carotenoids have been reported to exhibit chemoprevention by a variety of mechanisms including immune system activation, protection against oxidative stress, promotion of gap junction communication, inhibition of DNA damage, enhanced metabolic detoxification, and tumor suppressor action and inhibition of oncogene expression (Khachik et al. 1999; Fiedor and Burda 2014).

Potato carotenoid concentrations and profiles are related to the flesh color with dark yellow cultivars showing approximately tenfold higher concentrations of total carotenoids than white-fleshed varieties (Brown et al. 2005). Significant and predominant amounts of zeaxanthin and antheraxanthin are found in deep yellowfleshed potatoes while the carotenoid profile of yellow potatoes is composed of violaxanthin, antheraxanthin, lutein, and zeaxanthin and that of cream-fleshed potatoes of violaxanthin, lutein, and $\beta$-carotene (Burgos et al. 2009).

The violaxanthin, antheraxanthin, lutein, and $\beta$-carotene concentration of raw tubers of potatoes from the Tuberosum group ranged from 1.5 to $87.8 \mu \mathrm{g} / 100 \mathrm{~g} \mathrm{FW}$, 0.6 to $15.8 \mu \mathrm{g} / 100 \mathrm{~g} \mathrm{FW} ; 1.6$ to $35.1 \mu \mathrm{g} / 100 \mathrm{~g} \mathrm{FW}$; and 0.1 to $2.1 \mu \mathrm{g} / 100 \mathrm{~g} \mathrm{FW}$, respectively (Fernandez-Orozco et al. 2013), while the concentration of these carotenoids in tubers from the Phureja group ranged from 20.0 to $410 \mu \mathrm{g} / 100 \mathrm{~g} \mathrm{FW} ; 9.3$ to $503 \mu \mathrm{g} / 100 \mathrm{~g} \mathrm{FW} ; 55$ to $211 \mu \mathrm{g} / 100 \mathrm{~g} \mathrm{FW}$ and 4.8 to $27 \mu \mathrm{g} / 100 \mathrm{~g} \mathrm{FW}$, respectively (Burgos et al. 2009), and in tubers from the Andigenum group from 14.3 to $173 \mu \mathrm{g} / 100 \mathrm{~g} \mathrm{FW}, 7$ to $16 \mu \mathrm{g} / 100 \mathrm{~g} \mathrm{FW} ; 43.3$ to $442 \mu \mathrm{g} / 100 \mathrm{~g} \mathrm{FW}$ and 10.5 to $54.8 \mu \mathrm{g} / 100 \mathrm{~g} \mathrm{FW}$, respectively (Andre et al. 2007).

Boiling does not affect the lutein and zeaxanthin concentration of potato; however, violaxanthin and antheraxanthin concentrations of potatoes are significantly reduced after boiling. Lutein and zeaxanthin concentrations of cooked yellowfleshed potatoes ranged from 73 to $253 \mu \mathrm{g} / 100 \mathrm{~g}$ FW and from 0 to $1048 \mu \mathrm{g} / 100 \mathrm{~g}$ FW, respectively (Burgos et al. 2012) with deep yellow-fleshed potatoes being a significant source of zeaxanthin (above $500 \mu \mathrm{g} / 100 \mathrm{~g} \mathrm{FW}$ ).

Lutein and zeaxanthin are important dietary carotenoids that are selectively taken up into the macula of the eye, where they protect against development of agerelated macular degeneration and cataracts (Wu et al. 2015). Moreover, these compounds have been reported to have other health-promoting effects, including immune-enhancement and reduction of the risk of developing degenerative diseases such as cancer and cardiovascular diseases (Krinsky and Johnson 2005). There is no recommended daily intake for lutein and zeaxanthin, but many studies show a health benefit for lutein supplementation at $10 \mathrm{mg}$ per day and zeaxanthin at $2 \mathrm{mg}$ per day (American Optometric Association 2009).

The highest values of lutein and zeaxanthin reported in $100 \mathrm{~g}$ of yellow-fleshed potatoes are lower compared to the amount of lutein provided by $100 \mathrm{~g}$ of lettuce

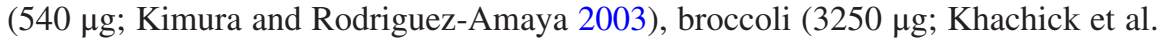


1992), parsley (5800 $\mu \mathrm{g}$; Hart and Scott 1995), or spinach (4180 $\mu \mathrm{g}$; Tee and Lim 1991); and lower than the amount of zeaxanthin provided by $100 \mathrm{~g}$ of maize at its highest zeaxanthin concentration $(3800 \mu \mathrm{g} / 100 \mathrm{~g})$ (Brenna and Berardo 2004) and of red paprika (2200 $\mu \mathrm{g} / 100 \mathrm{~g}$ ) (Müller 1997; Mínguez Mosquera and HorneroMéndez 1994). However, it is important to consider that potato consumption can be as high as $500 \mathrm{~g}$ per day whereas the mean intake of the above-mentioned vegetables is less than $50 \mathrm{~g}$ per day; hence, the overall contribution of potato-based carotenoids to the dietary intake can be higher. Furthermore, the contribution of a food source to lutein and zeaxanthin intake depends on their digestive stability, bioaccessibility, and bioavailability in the respective food matrix. Bioaccessibility refers to the proportion of ingested carotenoid that is released from the food matrix and incorporated into micelles in the gastrointestinal tract, and thus available for intestinal absorption (Rodriguez-Amaya 2015). Bioavailability refers to the portion of the carotenoid that is absorbed in the body, enters in systemic circulation and becomes available for utilization in normal physiological functions or for storage in the human body (van Het Hof et al. 2000). The bioavailability of carotenoids from plant foods is influenced by the species and structure of carotenoids present in the food, composition, and release of carotenoids from the food matrix, absorption in the intestinal tract, transportation within the lipoprotein fractions, biochemical conversions, and tissue-specific depositions, as well as by the nutritional status of the ingesting consumer (Bohn 2017). Research on bioavailability of potato carotenoids is required to have more useful and complete information regarding their nutritional and health benefits.

Burgos et al. (2013a) evaluated the in vitro digestive stability and the efficiency of micellarization or bioaccessibility of lutein and zeaxanthin in yellow-fleshed potatoes. The gastric and duodenal digestive stability of lutein and zeaxanthin in boiled tubers ranged from 70 to $95 \%$ while the bioaccessibility ranged from 33 to $71 \%$ for lutein and from 51 to $71 \%$ for zeaxanthin. A more recent study has reported that bioaccessibility of lutein and zeaxanthin in yellow-fleshed clones range from 76 to $82 \%$ for lutein and from 24 to $55 \%$ for zeaxanthin (Andre et al. 2015).

The maximum bioaccessible lutein concentration reported in yellow-fleshed potatoes is around $300 \mu \mathrm{g} / 100 \mathrm{~g} \mathrm{FW}$ while the maximum bioaccessible zeaxanthin concentration is around $600 \mu \mathrm{g} / 100 \mathrm{~g} \mathrm{FW}$. Considering the mean potato intake in the Andes of Peru, Ecuador, and Bolivia (500 g per day), potato tubers from the variety with the highest bioaccessible lutein could provide $14 \%$ of the suggested level of lutein intake for having health benefit (10 mg per day). Likewise, potato tubers of the variety with the highest bioaccessible zeaxanthin concentration could provide $50 \%$ more than the suggested level of zeaxanthin intake ( $2 \mathrm{mg}$ per day). In Spain, potato was shown to contribute $13-20 \%$ towards the total dietary intake of zeaxanthin and was ranked as the third main contributor after citrus fruits and green vegetables (Garcia-Closas et al. 2004). More population studies are needed, however, regarding the nutritional and health contributions of carotenoids as provided by potatoes. 


\subsection{Antioxidant Activity}

Antioxidant activity (AA) describes the capacity of redox molecules in foods and biological systems to scavenge free radicals considering the additive and synergistic effects of all antioxidants rather than the effect of single compounds, and may, therefore, be useful to study the potential health benefits of antioxidants on oxidative stress-mediated diseases (Puchau et al. 2010). In that context, mixtures of phytochemicals found in plant foods are more effective in improving antioxidant status than isolated phytochemicals (DeGraft-Johnson et al. 2007). The antioxidant activity of foods as assessed by indices such as ferric reducing ability of plasma (FRAP) has been indicated to be a valid and reproducible determinant of human plasma AA measurements (Rautiainen et al. 2008). Antioxidant capacities of food staples such as potatoes could thus potentially affect the antioxidant status of that population.

The antioxidants in potato are mainly hydrophilic (polyphenols, ascorbic acid, anthocyanins, and flavanols) (Fig. 2.3) (Reyes et al. 2005). In white- or yellowfleshed potatoes, prevalent contributors of AA are chlorogenic acid, gallic acid, caffeic acid, and catechin (Reddivari et al. 2007a), while in purple- and red-fleshed potatoes the major contributors to AA are anthocyanins and chlorogenic acid (Lachman et al. 2009). Potatoes also contain lipophilic antioxidants (carotenoids and vitamin E) (Fig. 2.4).

Because antioxidant activity of potato anthocyanins results from the synergistic effect of each anthocyanin pigment (Hayashi et al. 2003), it is important to assess different pigmented potato cultivars for individual anthocyanidin content, as well as the contribution of the anthocyanidin composition to their antioxidant activity. A high degree of hydroxylation and/or methoxylation of individual anthocyanidins could contribute in conjunction with other phenolics to high AA (Lachman et al. 2009).

Burgos et al. (2013b) reported that boiled potatoes of purple-fleshed potato varieties have an AA ranging from 4017 to $17,304 \mathrm{mg}$ Trolox equivalents (TEq)/g, FW as determined by the 2,2-azino-bis-3-ethylbenzthiazoline-6-sulfonic acid (ABTS) antioxidant capacity measure and from 2369 to $9754 \mathrm{mg}$ TEq/g, FW as determined by 1,1-diphenyl-2-picryl-hydrazyl (DPPH) antioxidant capacity assay. Compared to other sources of antioxidants, potato has lower AA than strawberry, blackberry, and blueberry as determined by the ABTS assay (around 25,030-50,000 mg TEq/g, FW, Garcia-Alonso et al. 2004). However, as indicated above the overall contribution of potato to the antioxidant intake of a population will finally depend in the amount of potatoes typically consumed.

Ombra et al. (2015) reported after simulated gastrointestinal digestion, the extracts from purple potato have high in vitro antioxidant, antimicrobial, and anti-proliferative activities against the colon cancer cells Caco-2 and SW48 and the breast cancer cells MCF-7 and MDA-MB-231.

After digestion of cooked tubers from purple-fleshed potatoes using a dynamic human gastrointestinal model, Kubow et al. (2017) found an increased FRAP anti- 
<smiles>O=C1O[C@H]([C@@H](O)CO)C(O)=C1O</smiles>

Ascorbic Acid<smiles>C[C@@H]1O[C@H](OC[C@H]2O[C@H](Oc3c(-c4ccc(O)c(O)c4)oc4cc(O)cc(O)c4c3=O)[C@H](O)[C@@H](O)[C@H]2O)[C@H](O)[C@@H](O)[C@H]1O</smiles>

Rutin

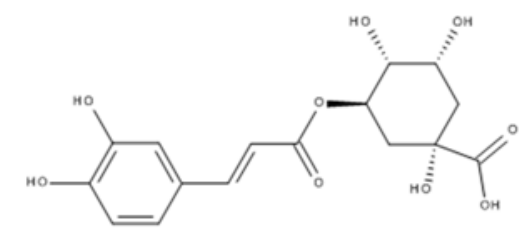

Chlorogenic Acid

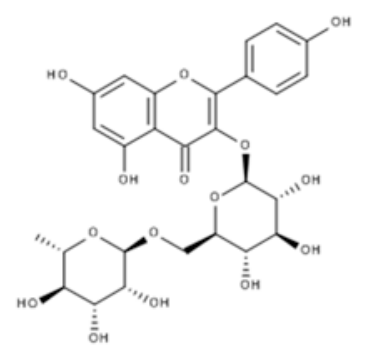

Kaempferol-3-rutinoside

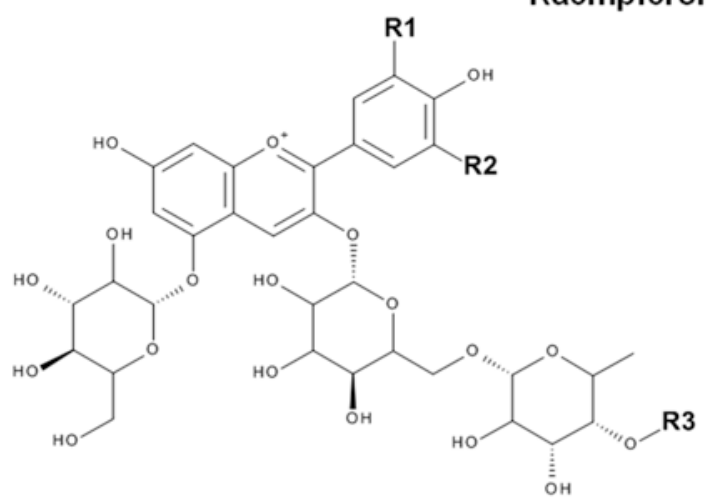

\begin{tabular}{c|ccc} 
Anthocyanins & R1 & R2 & R3 \\
\hline pet-3-coum-rut-5-glc & OMe & $\mathrm{OH}$ & p-coumaric acid \\
peo-3-coum-rut-5-glc & $\mathrm{OMe}$ & $\mathrm{H}$ & p-coumaric acid \\
cyan-3-coum-rut-5-glc & $\mathrm{OH}$ & $\mathrm{H}$ & p-coumaric acid \\
mal-3-coum-rut-5-glc & $\mathrm{OMe}$ & $\mathrm{OMe}$ & p-coumaric acid \\
pel-3-coum-rut-5-glc & $\mathrm{H}$ & $\mathrm{H}$ & p-coumaric acid
\end{tabular}

Fig. 2.3 Chemical structure of hydrophilic antioxidants in potato 


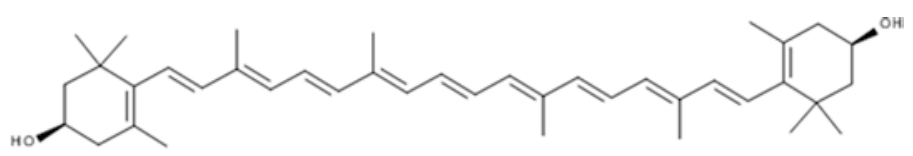

\section{zeaxanthin}
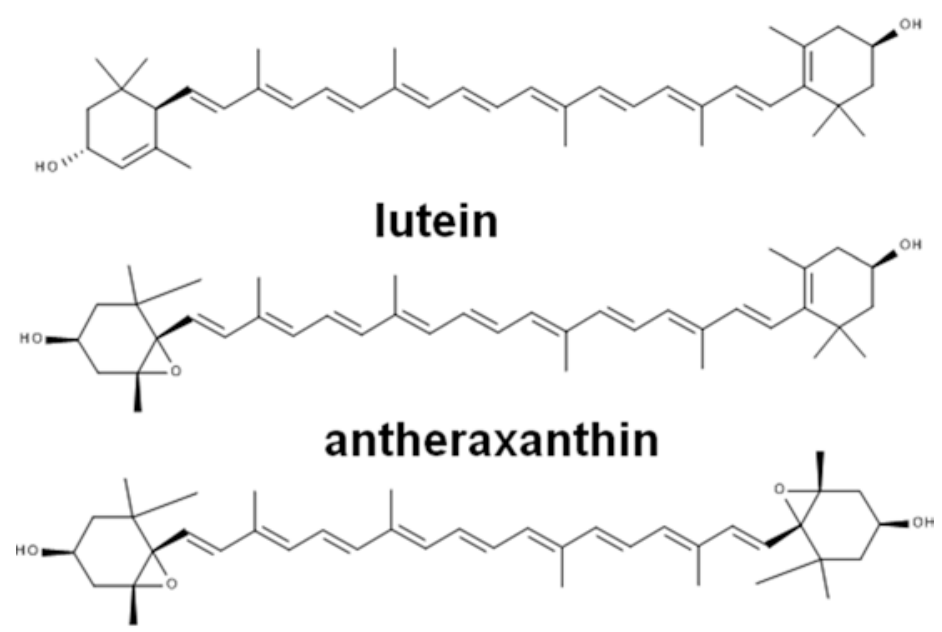

violaxanthin
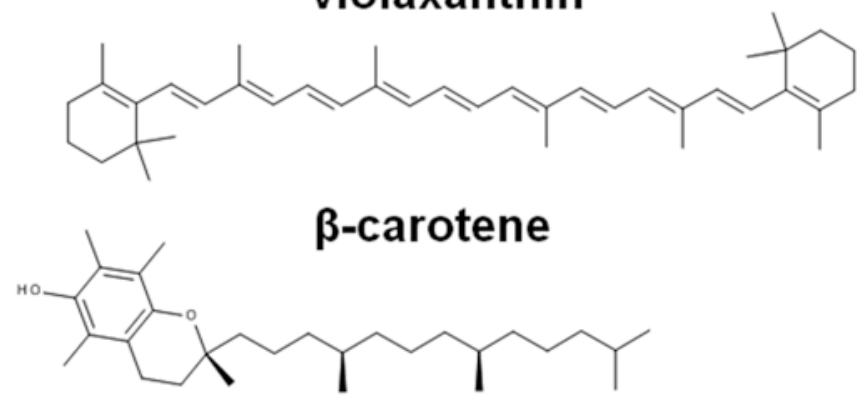

\section{a-tocopherol}

Fig. 2.4 Chemical structure of lipophilic antioxidants in potato

oxidant activity in the colonic reactors. Metabolic microbial breakdown of anthocyanins over a $24 \mathrm{~h}$ period appeared to generate sufficient amounts of microbial metabolites to produce an improvement in antioxidant capacity. Anthocyanins and their metabolites can, via antioxidant activity, provide protection for intestinal cells against oxidative stress in the gut, and hence alleviate gut inflammation, protect against colorectal cancer, and generally enhance colorectal health. 


\subsection{Glycoalkaloids}

Glycoalkaloids are secondary plant metabolites that serve as natural defenses against bacteria, fungi, viruses, and insects (Friedman 2004). They can be toxic for humans when present in high concentrations, and can impart a bitter taste to potatoes. However, glycoalkaloids and hydrolysis products without the carbohydrate side chain (aglycones) also have beneficial effects that include: lowering of cholesterol (Friedman et al. 2003) and inhibition of the growing of cancer cells in culture as well as tumor growth in vivo (Friedman 2015).

Although there are many glycoalkaloids, $\alpha$-chaconine and $\alpha$-solanine make up $95 \%$ of the total glycoalkaloids present (Friedman et al. 1997); $\alpha$-solanine is found in greater concentrations than $\alpha$-chaconine, and $\alpha$-solanine has only half as much specific toxic activity as a $\alpha$-chaconine (Lachman et al. 2001).

Experiments with human taste panels revealed potato varieties with glycoalkaloid levels exceeding $14 \mathrm{mg} / 100 \mathrm{~g} \mathrm{FW}$ tasted bitter (Friedman 2006). Those in excess of $22 \mathrm{mg} / 100 \mathrm{~g} \mathrm{FW}$ also induced mild to severe burning sensations in the mouths and throats of panel members.

Glycoalkaloid levels vary greatly in different potato varieties and may be influenced by factors such as light, mechanical injury, and storage. They are also influenced by stress such as heat and drought during production. This raises concern for maintaining the quality of potatoes under climate change (Andre et al. 2009), and suggests increased attention may be needed to glycoalkaloid concentrations of potato varieties bred for or grown in warm environments.

Glycoalkaloid concentration of raw potatoes ranges from 0.7 to $18.7 \mathrm{mg} / 100 \mathrm{~g}$ FW (Friedman et al. 2003). Peeling significantly reduced the glycoalkaloid levels in the tubers: solanine to $43.6 \%$ and chaconine to $31 \%$ (Lachman et al. 2013). Cooking also significantly reduced the levels of glycoalkaloids (Tajner-Czopek et al. 2008), with boiling reducing the levels of glycoalkaloids more than baking and microwaving (Lachman et al. 2013).

Glycoalkaloid content in potato tubers should not exceed $20 \mathrm{mg} / 100 \mathrm{~g} \mathrm{FW}$, because this level is dangerous for human health (Ruprich et al. 2009). The toxicity of glycoalkaloids at appropriate high levels may be due to adverse effects such as anticholinesterase activity on the central nervous system and to disruption of cell membranes adversely affecting the digestive system and general body metabolism (Friedman et al. 2003). The toxicity of glycoalkaloids is associated with the synergistic interaction between two main components of glycoalkaloids: $\alpha$-solanine and $\alpha$-chaconine.

However, glycoalkaloids also have anti-carcinogenic properties. Exposure of cancer cells to glycoalkaloids produced potatoes ( $\alpha$-chaconine and $\alpha$-solanine) or their hydrolysis products (mono-, di-, and trisaccharide derivatives and the aglycones solasodine, solanidine, and tomatidine) inhibits the growth of the tumor cells in culture as well as in vivo tumor growth (Friedman 2015). On the basis of the anticarcinogenic properties of these potato components, it is conceivable that the levels typically noted in commercial potatoes might help to protect against multiple cancers. Epidemiological studies, however, are needed to substantiate this possibility. 


\subsection{Contribution to Health}

Population-based epidemiological studies have emphasized the importance of nutrition to combat metabolic disorders emerging worldwide that have been associated with diet, such as diabetes, cancer, and cardiovascular diseases. In that regard, higher intakes of fruits and vegetables have been consistently indicated to exert protective effects against such chronic diseases (Dragsted et al. 2006). Potato has been underappreciated relative to other vegetables as it has been subject to controversy such as being labeled as a contributor to development of obesity and diabetes (Burlingame et al. 2009). On the other hand, potatoes contain relatively high concentrations of key phytonutrients that have shown bioactivities that could counteract chronic disease development (Ezekiel et al. 2013). Potatoes have shown promising health-promoting effects in human cell culture, experimental animals, and human clinical studies, including anti-cancer, hypocholesterolemic, anti-inflammatory, anti-obesity, and anti-diabetic properties. Nutritional compounds of potatoes such as phenolics, anthocyanins, fiber, starch as well as compounds considered antinutritional such as glycoalkaloids, lectins, and proteinase inhibitors are believed to contribute to the health benefits of potatoes (Fig. 2.5). As there are many biological activities attributed to the compounds present in potato, some of which could be beneficial or detrimental depending on specific circumstances, long-term studies investigating the association between potato consumption and diabetes, obesity, cardiovascular disease, and cancer while controlling for fat intake are needed (Visvanathan et al. 2016).

\subsubsection{Anticancer Effect}

Several studies have shown a reduction in proliferation of cancer cells when treated with potato extracts. Potato antioxidants such as phenolic acids and anthocyanins, glycoalkaloids, fiber, and proteinase inhibitors identified in potatoes have been implicated in the suppression of cancer cell proliferation in vitro and in vivo.

\subsubsection{Role of Potato Antioxidants}

Phenolic acids and anthocyanins are potato antioxidants that have reported anticarcinogenic activity. Hayashi et al. (2006) reported that anthocyanins in steamed purple and red potatoes suppressed the growth of benzopyrene-induced stomach cancer in mice. Reddivari et al. (2007b) found that the anthocyanin fractions from potato extracts were cytotoxic to prostate cancer cells through activation of caspasedependent and caspase-independent pathways. Madiwale et al. (2011) reported that purple flesh potatoes rich in anthocyanins suppressed proliferation and elevated 


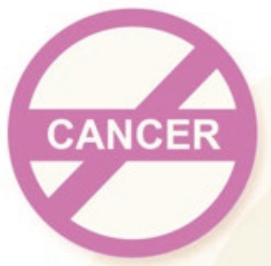

Anti-cancerigen

Chlorogenic acid

Anthocyanins

Glycoalkaloids Fiber

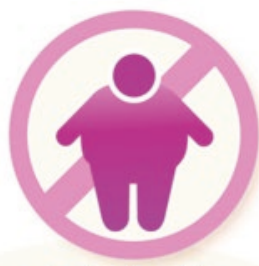

Anti-obesity

Resistant starch

Phosphorylated starch

Phenolics

Potato protein and

peptides

$$
\text { peptides }
$$

Anti-hypertensive

Anthocyanins

Potassium

Potato protein

and peptides

\section{THDL ILDL}

\section{Anti-hyperlipidemic}

Resistant starch

Phosphorylated starch

Fiber

Glycoalkaloids

Phenolics

Potato protein

and peptides

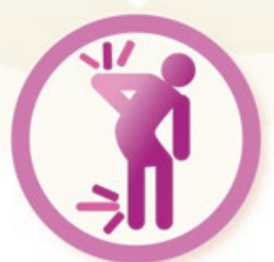

Anti-inflammatory

Anthocyanins

Glycoalkaloids

Vitamin C

Fig. 2.5 Health benefits of potatoes

apoptosis of colon cancer cells compared with white and yellow flesh potatoes. In a more recent study, Charepalli et al. (2015) found that extracts of purple-fleshed potatoes suppress colon tumorigenesis via elimination of colon cancer stem cells. Chlorogenic acid, the main phenolic acid of potato, is effective against human liver, colon, and prostate cancer cells (Wang et al. 2011) and inhibits significantly the proliferation of colon cancer and prostate cancer cells. 


\subsubsection{Role of Potato Glycoalkaloids}

$\alpha$-Solanine and $\alpha$-chaconine, the main steroidal glycoalkaloids in potatoes, are well studied for their antitumor properties (Friedman 2015). Lee et al. (2004) found that $\alpha$-solanine exhibited growth inhibition and apoptosis induction in multiple cancer cells such human colon (HT29) and liver (HepG2) cancer cells. Friedman et al. (2005) evaluated the anti-carcinogenic effect of $\alpha$-solanine and $\alpha$-chaconine extracted from five fresh potato varieties (Dejima, Jowon, Sumi, Toya, and Vora Valley) and found that glycoalkaloids exerted anti-proliferative effects of the following human tumor cell lines: cervical (HeLa), liver (HepG2), lymphoma (U937), stomach (AGS and KATO III) cells, and on normal liver (Chang) cells. Friedman et al. (2005) also reported that the anti-proliferative effects of the glycoalkaloids were concentration dependent and that $\alpha$-chaconine was more bioactive than $\alpha$-solanine. Yang et al. (2006) found that $\alpha$-chaconine induced the apoptosis of HT-29 human colon cancer cells through caspase-3 activation and inhibition of extracellular signal-regulated kinase phosphorylation.

Reddivari et al. (2010) showed that $\alpha$-chaconine exhibited potent anti-proliferative properties and increased cyclin-dependent kinase inhibitor p27 levels in two prostate cancer cell lines, $\mathrm{LNCaP}$ and PC3. More recently, it has been reported that $\alpha$-solanine, has a positive effect on the inhibition of pancreatic cancer cell growth in vitro and in vivo. Sun et al. (2014) demonstrated that $\alpha$-solanine inhibited cancer cell growth through caspase 3-dependent mitochondrial apoptosis and that the expression of tumor metastasis-related proteins, MMP-2 and MMP-9, was also decreased in the cells treated with $\alpha$-solanine. Lv et al. (2014) reported that $\alpha$-solanine inhibited proliferation of PANC-1, sw1990, MIA PaCa-2 cells in a dosedependent manner, as well as cell migration and invasion with a toxic dose and that the administration of $\alpha$-solanine during 2 weeks in a xenograft model reduces the tumor volume and weight by $43-61 \%$. These studies showed beneficial effects on pancreatic cancer in vitro and in vivo, which may be mediated via suppressing pathways involving proliferation, angiogenesis, and metastasis.

\subsubsection{Role of Potato Fiber}

Langner et al. (2009) reported that commercially available potato fiber extract (Potex) exhibited anti-proliferative effects in several tumor cell cultures. The fiber extract decreased cancer cell motility, induced apoptosis, and also caused morphological changes in tumor cells.

\subsection{Anti-diabetic and Anti-obesity Effects}

Potato consumption has often been associated in cohort studies with elevated risk of type 2 diabetes (Muraki et al. 2016) and obesity (Borch et al. 2016), which has been attributed to a relatively high glycemic index in some potato varieties and processed 
potato products containing added saturated and trans fats. A major confounding factor in such studies is typical Western dietary patterns associated with increased disease risk typically include potato consumption along with high intake of red and processed meat, refined grains, high-fat dairy products, fried foods and sugar (Pastorino et al. 2016). More research is needed to adjust association of food items such as potatoes in such dietary patterns (Hu 2002). Moreover, RDS present in cooked potatoes (especially amylose) tends to retrograde upon cooling generating appreciable amounts of slowly digestible starch (SDS) or resistant starch (RS) that contribute to dietary fiber content (Sajilata et al. 2006) and potentially positively impact health by slowing postprandial glucose release from cooked potatoes (King and Slavin 2013).

GI values below 56 are considered as low glycemic index while values above 74 are considered to indicate a high glycemic index. GI values in potato ranged from 56 to 94 for eight British cultivars (Henry et al. 2005) and from 53 to 103 for seven Australian cultivars (Wang et al. 2014). When boiled red potatoes were served hot to volunteers, a GI of 89.4 was found (Fernandes et al. 2005). When cooking is followed by cooling, amylose retrogrades to produce resistant starch. The GI response was only 56.2 when cooking was followed by refrigeration of 12-24 h.

Potato chips and French fries have been implicated by some nutrition researchers as major contributors to obesity risk as these products contain a high fat and caloric content. Potato servings, however, are not likely in themselves to promote obesity as potatoes are considered to have a low energy density as they are a low-fat food with a high-water content (Anderson et al. 2013). Potato-based foods with high calorie fat additions have been considered as a major culprit towards obesity risk (Camire et al. 2009).

Conversely, potatoes may have a role in controlling appetite and therefore weight gain, by contributing to satiety. Satiety is the feeling of fullness and the loss of hunger that occur after eating. Many factors influence satiety, including the rate of gastric emptying and the proportion of macronutrients in the food. Foods that increase satiety are thought to promote weight control by delaying subsequent meals and total calories consumed (Camire et al. 2009). Compared to rice and pasta, adult feeding studies have shown that satiating amounts of potatoes co-ingested with meat resulted in lower energy intake and postprandial insulin concentrations; and higher levels of ghrelin, which is a gastric orexigenic appetite-stimulating hormone that contributes to feeding regulation (Erdmann et al. 2007). Likewise, studies involving children showed that meat co-ingestion with boiled mashed potato resulted in an approximate $40 \%$ lower energy intake as compared to meat consumed together with either pasta or rice (Akilen et al. 2016). The stronger satiety of boiled mashed potato for the calories consumed was related to similar suppression of ghrelin postprandially relative to the other carbohydrate-rich foods despite the lower potato meal intake. Short-term intervention studies have generally indicated that high GI meals decrease satiety, and an increase in the return of hunger and energy intake at a later meal as opposed to low glycemic index meals containing potatoes (Roberts 2000). 


\subsection{Anti-hyperlipidemic, Anti-hypertensive and Anti-inflammatory Effects}

A variety of animal feeding studies have shown cholesterol-lowering properties from potato intake that have been related to its content of protein, resistant and phosphorylated starch, fiber, glycoalkaloids (Friedman 2006), and phenolic compounds (Friedman 1997). Robert et al. (2006) found that consumption of cooked potatoes (consumed with skin) improved lipid metabolism in cholesterol-fed rats. Rats fed a potato-enriched diet for 3 weeks had lower concentrations of plasma cholesterol and triglycerides and reduced liver cholesterol content. Hashimoto et al. (2006) showed that retrograded starch from two varieties of potato pulp lowered serum total cholesterol and triglyceride concentrations. The authors indicated that the retrograded starch promoted the excretion of bile acids resulting in a low concentration of serum cholesterol; and that retrograded starch inhibited the synthesis of fatty acids at the mRNA levels of fatty acid synthase (FAS) and SREBP-1c, which might be related to the observed reduction of the serum triglyceride concentrations. Kanazawa et al. (2008) reported that gelatinized potato starch containing a high level of phosphate reduced concentrations of serum-free fatty acids and triglycerides and liver triglycerides.

Liyanage et al. (2008) have demonstrated the hypocholesterolemic effect of potato peptides. Rats fed a cholesterol-free diet containing $20 \%$ (w/w) potato peptides showed greater concentrations of serum high-density lipoprotein (HDL) cholesterol and increased fecal steroid output and lesser non-HDL cholesterol concentrations than rat fed diets containing $20 \%$ casein peptides. The results were attributed to inhibition of cholesterol absorption, possibly via suppression of micellar solubility of cholesterol. In a follow-up study, Liyanage et al. (2009) found that potato peptides reduced the serum non-HDL cholesterol concentrations by stimulating fecal steroid excretion, accelerated by cecal short-chain fatty acids in a hypercholesterolemic rat model. There is a lack of data, however, from randomized controlled trials to demonstrate a relationship between potato consumption and blood lipid parameters in humans.

Vinson et al. (2012) showed a significant lowering of systolic blood pressure in humans after supplementation to hypertensive subjects in a 4-week cross-over trial involving consumption of six to eight small purple potatoes twice daily versus no potato intake. The blood pressure lowering effect was related to high intake of polyphenols associated with the pigmented potatoes. This latter intervention trial is contrasted by an analysis from three large prospective cohort studies indicating increased hypertension risk in association with potato intake of four or more servings per month as opposed to one serving per month (Borgi et al. 2016). A major limitation of such trials is that co-ingestion of salt, high-salt foods, saturated or trans fats with potatoes could have contributed to the hypertension risk as opposed to potato per se, particularly since potatoes are typically eaten in a meal context (Miller and Stanner 2016). In support of this contention, a 3-year longitudinal study of Japanese people showed that adherence to a traditional Japanese dietary pattern 
exerted favorable effects on blood pressure that was partly associated with potato intake (Niu et al. 2016).

Relatively high intake of potassium is needed to counteract the blood pressure raising effects of a high sodium diet and so protect against hypertension (Camire et al. 2009). An increase in consumption of potassium-rich foods has been promoted to combat hypertension and cardiovascular disease (WHO 2012). In that regard, intake of potassium-rich foods has been indicated to protect against stroke risk (Adebamowo et al. 2015). As potatoes are rich in potassium and are naturally very low in sodium content, this food could counter development of hypertensionassociated diseases. Additionally, Makinen et al. (2008) reported that a protein isolated from vascular bundle and inner tuber tissues of potato enhanced the inhibition of the angiotensin converting enzyme I, a biochemical factor affecting blood pressure that contributes to hypertension.

Kaspar et al. (2011) found anti-inflammatory effects in healthy men consuming white and pigmented potatoes with greater effects from pigmented potatoes. Potato phenolics and glycoalkaloids have shown evidence of anti-inflammatory activities (Kenny et al. 2013). Indigestible carbohydrates including resistant starch and fiber have demonstrated the ability to modulate inflammatory markers in both animal models (Vaziri et al. 2014) and human clinical trials (Jiao et al. 2015). Hence, the contribution of resistant starch or fiber from select potato products may have also direct impact on inflammatory stress in humans.

\subsection{Potato and Its Relationship with Cardiovascular Diseases}

As a key dietary source of potassium, vitamin C, and dietary fiber, potatoes contribute significantly to nutrients with defined roles in promoting cardiovascular health (McGill et al. 2013). Boiled potatoes have been shown to have favorable impact on several measures of cardiometabolic health in animals and humans, including lowering blood pressure, improving lipid profiles, and decreasing markers of inflammation (McGill et al. 2013). When eaten as a regular food item and consumed with skin, potato intake can significantly enhance cardioprotective fiber intake that is generally lacking in Western-type diets (Lockyer et al. 2016). Large prospective studies in Sweden involving a 13-year follow-up showed no adverse relationship of higher potato intake with cardiovascular risk for either morbidity or mortality (Larsson and Wolk 2016). Similarly, a systematic review of five observational studies carried out by Borch et al. (2016) showed no convincing evidence to support an adverse association between unprocessed potato intake and the risk of developing metabolic disorders including obesity, type 2 diabetes, and cardiovascular disease. On the other hand, processed potato products like French fries and potato crisps, with high lipid and trans fats content and added sodium can have adverse effect of the heart health and so should be minimized in the diet. In that regard, despite the lack of a relationship between chronic disease risk and potato intake in the above comprehensive review by Borch et al. (2016), they showed that French 
fries and fried potato were associated with an increased risk for obesity and type 2 diabetes. Likewise, a longitudinal study involving 4440 subjects with an 8-year follow-up showed no association between higher potato intake and mortality risk, whereas participants who consumed fried potatoes two to three times/week had an increased mortality risk (Veronese et al. 2017). Camire et al. (2009) have recommended preparing potatoes with minimum lipid addition and consume potatoes with peels to conserve their cardiovascular health promoting properties.

\subsection{Concluding Remarks}

Potato is an important source of carbohydrates, resistant starch, quality protein, vitamins C and B6 as well as potassium. Potatoes are also a source of antioxidants. Chlorogenic acid and glycoalkaloids are present in all potatoes independently of the flesh color while deep yellow-fleshed potatoes contain high amounts of lutein and zeaxanthin; and purple-fleshed potatoes contain high amounts of anthocyanins. Potatoes glycoalkaloids in high concentrations can be toxic to humans but in low concentrations can have beneficial effects such as inhibition of the growth of cancer cells.

The contribution of potato to the diet is affected by cooking, potato intake, and the bioavailability of potato nutrients. Potato vitamins are significantly reduced after cooking. However, $100 \mathrm{~g}$ of cooked potatoes provide around $30 \%$ of the requirement of vitamin $\mathrm{C}$ and $20 \%$ od the requirement of vitamin B6. Potato carotenoids and anthocyanins show high recoveries after cooking due to an improved release of these antioxidants. In vitro studies demonstrate that potato lutein and zeaxanthin have a high bioaccessibility and that potato phenolics undergo microbial transformation in the intestinal tract producing metabolites that may also promote a healthy gut microbiome. Further research in humans is needed to confirm the beneficial effect of potato phenolics in the gut.

In areas where potato is consumed in large quantities like in the highlands of Latin American countries, the potato contribution to the energy, protein, iron, and zinc intake is significant. In those areas, iron and zinc biofortified potatoes are expected to contribute to reduce malnutrition and anemia. Nevertheless, to assess the full potential of the biofortified potatoes, human studies are required to gain insight on how much of the iron from biofortified potatoes are absorbed by the human body.

Regarding its contribution to human health, potatoes have shown promising health-promoting effects in human cell culture, experimental animals, and human clinical studies. Potato compounds such as phenolic acids and anthocyanins, glycoalkaloids, fiber, and proteinase inhibitors have been implicated in the suppression of cancer cell proliferation in vitro and in vivo and are believed to contribute to the hypocholesterolemic, anti-inflammatory, anti-obesity and anti-diabetic properties of potato. 


\section{References}

Adebamowo SN, Spiegelman D, Willett WC (2015) Association between intakes of magnesium, potassium, and calcium and risk of stroke: 2 cohorts of US women and updated metaanalyses. Am J Clin Nutr 101:1269-1277

Akilen R, Deljoomanesh N, Hunschede S, Smith CE, Arshad MU, Kubant R, Anderson GH (2016) The effects of potatoes and other carbohydrate side dishes consumed with meat on food intake, glycemia and satiety response in children. Nutr Diabetes 6:e195. https://doi.org/10.1038/ nutd.2016.1

American Optometric Association (2009) Diet, nutrition and eye health. http://www.aoa.org/documents/nutrition/Diet_Nutrition_Eye_Health_booklet.pdf. Accessed 28 Sept 2017

Amrein T, Bachmann S, Noti A, Biedermann M, Barbosa M, Biedermann-Brem S, Grob K, Keiser A, Realini P, Escher F, Amadó R (2003) Potential of acrylamide formation, sugars, and free asparagine in potatoes: a comparison of cultivars and farming systems. Agric Food Chem 51(18):5556-5560

Anderson GH, Soeandy CD, Smith CE (2013) White vegetables: glycemia and satiety. Adv Nutr 4(Suppl):356S-367S

Andre CM, Oufir M, Guignard C, Hoffmann L, Hausman JF, Evers D, Larondelle Y (2007) Antioxidant profiling of native Andean potato tubers (Solanum tuberosum L.) reveals cultivars with high levels of $\beta$-carotene, alpha-tocopherol, chlorogenic acid, and petanin. Agric Food Chem 55:10839-10849

Andre CM, Schafleitner R, Legay S, Lefèvre I, Aliaga CA, Nomberto G, Hoffmann L, Hausman JF, Larondelle Y, Evers D (2009) Gene expression changes related to the production of phenolic compounds in potato tubers grown under drought stress. Phytochemistry 70:1107-1116

Andre CM, Larondelle Y, Evers D (2010) Dietary antioxidants and oxidative stress from a human and plant perspective: a review. Curr Nutr Food Sci 6(1):2-12

Andre CM, Evers D, Ziebel J, Guignard C, Hausman JF, Bonierbale M, zum Felde T, Burgos G (2015) In vitro bioaccessibility and bioavailability of iron from potatoes with varying vitamin C, carotenoid, and phenolic concentrations. J Agric Food Chem 63(41):9012-9021. https://doi. org/10.1021/acs.jafc.5b02904

Auestad N, Hurley J, Fulgoni V, Schweitzer CM (2015) Contribution of food groups to energy and nutrient intakes in five developed countries. Nutrients 7:4593-4618

Bach S, Yada RY, Bizimungu B, Fan M, Sullivan JA (2013) Genotype by environment interaction effects on starch content and digestibility in potato (Solanum tuberosum L.). J Agric Food Chem 61(16):3941-3948. https://doi.org/10.1021/jf3030216. Epub 2013 Apr 12

Bamberg JB, del Rio A (2005) Conservation of potato genetic resources. In: Razdan MK, Mattoo AK (eds) Genetic improvement of solanaceous crops. Volume I: Potato. Science Publishers, Inc., Plymouth, p 476

Bates C (1997) Vitamin Analysis. Ann Clin Biochem 34(6):599-626. https://doi.org/10.1177/000 456329703400604

Bethke P, Jansky S (2018) The Effects of Boiling and Leaching on the Content of Potassium and Other Minerals in Potatoes. J Food Sci 73(5):H80-H85

Bohn T (2017) Bioactivity of carotenoids-chasms of knowledge. Int J Vitam Nutr Res 10:1-5. https://doi.org/10.1024/0300-9831/a000400

Bonierbale M, Burgos G, zum Felde T, Sosa P (2010) Composition nutritionnelle des pommes de terre. Cahiers de nutrition et dietétique 45:S28-S36

Borch D, Juul-Hindsgaul N, Veller M, Astrup A, Jaskolowski J, Raben A (2016) Potatoes and risk of obesity, type 2 diabetes, and cardiovascular disease in apparently healthy adults: a systematic review of clinical intervention and observational studies. Am J Clin Nutr 104:489-498

Borgi L, Rimm EB, Willett WC, Forman JP (2016) Potato intake and incidence of hypertension: results from three prospective US cohort studies. BMJ 353:i2351. https://doi.org/10.1136/bmj. i 2351 
Bramley PM, Elmadfa I, Kafatos A, Kelly FJ, Manios Y, Roxborough HE, Schuch W, Sheehy PJ, Wagner JH (2000) Vitamin E. J Sci Food Agric 80:913-938

Brenna O, Berardo N (2004) Applications of near-infrared reflectance spectroscopy (NIRS) to the evaluation of carotenoids in maize. J Agri Food Chem 52:5577-5582

Brennan CS (2005) Dietary fibre, glycaemic response, and diabetes. Mol Nutr Food Res 49:560-570

Brown CR, Wrolstad R, Durst R, Yang P, Clevidence B (2003) Breeding studies in potatoes containing high concentrations of anthocyanins. Am J Pot Res 80:241. https://doi.org/10.1007/ BF02855360

Brown CR, Culley D, Yang CP, Durst R, Wrolstad R (2005) Variation of anthocyanin and carotenoid contents and associated antioxidant values in potato breeding lines. J Am Soc Hortic Sc 130:174-180

Burgos G (2014) Concentración y bioaccesibilidad de carotenoides y compuestos fenólicos en papas cocidas. Tesis doctoral. Universidad de la Laguna. Departamento de Química Analítica, Nutrición y Bromatología

Burgos G, Amoros W, Morote M, Stangoulis J, Bonierbale M (2007) Iron and zinc concentration of native Andean potato varieties from a human nutrition perspective. J Sci Food Agric 87(4):668-675

Burgos G, Salas E, Amoros W, Auqui M, Munoa L, Kimura M, Bonierbale M (2009) Total and individual carotenoid profiles in the Phureja group of cultivated potatoes: I. concentrations and relationships as determined by spectrophotometry and high performance liquid chromatography (HPLC). J Food Compos Anal 22:503-508

Burgos G, Amoros W, Salas E, Muñoa L, Sosa P, Díaz C, Bonierbale M (2012) Carotenoid concentrations of native Andean potatoes as affected by cooking. Food Chem 133:1131-1137

Burgos G, Muñoa L, Sosa P, Bonierbale M, Zum Felde T, Díaz C (2013a) In vitro bioaccessibility of lutein and zeaxanthin of yellow fleshed boiled potatoes. Plant Foods Hum Nutr 68(4):385-390

Burgos G, Amoros W, Muñoa L, Sosa P, Cayhualla E, Sanchez C, Diaz C, Bonierbale M (2013b) Total phenolic, total anthocyanin and phenolic acid concentrations and antioxidant activity of purple-fleshed potatoes as affected by boiling. J Food Compos Anal 30:6-12

Burlingame B, Mouille B, Charrondiere R (2009) Nutrients, bioactive non-nutrients and antinutrients in potatoes. J Food Compos Anal 22:494-502

Camire ME, Kubow S, Donnelly DJ (2009) Potatoes and human health. Crit Rev Food Sci Nutr 49:823-840

Cevallos-Casals B, Cisneros Zevallos L (2003) Stoichiometric and kinetic studies of phenolic antioxidants from Andean purple corn and red-fleshed sweet potato. J Agric Food Chem 51:3313-3319

Champ MMJ (2004) Physiological aspects of resistant starch and in vivo measurements. J AOAC Int 87:749-755

Charepalli V, Reddivari L, Radhakrishnan S, Vadde R, Agarwal R, Vanamala JK (2015) Anthocyanin-containing purple-fleshed potatoes suppress colon tumorigenesis via elimination of colon cancer stem cells. J Nutr Biochem 26(12):1641-1649. https://doi.org/10.1016/j. jnutbio.2015.08.005

Chitchumroonchokchai C, Diretto G, Parisi B, Giuliano G, Failla ML (2017) Potential of golden potatoes to improve vitamin A and vitamin E status in developing countries. PLoS One 12(11):e0187102

Chun J, Lee J, Ye L, Exler J, Eitenmiller RR (2006) Tocopherol and tocotrienol contents of raw and processed fruits and vegetables in the United States diet. J Food Compos Anal 19:196-204

Clifford M (1999) Chlorogenic acids and other cinnamates - nature, occurrence and dietary burden. J Sci Food Agric 79:362-372

Crapo PA, Reaven G, Olefsky J (1977) Postprandial plasma-glucose and -insulin responses to different complex carbohydrates. Diabetes 26:1178-1183

DeGraft-Johnson J, Kolodziejczyk K, Krol M, Nowak P, Krol B, Nowak D (2007) Ferric-reducing ability power of selected plant polyphenols and their metabolites: implications for clinical 
studies on the antioxidant effects of fruits and vegetable consumption. Basic Clin Pharmacol Toxicol 100:345-352

De Haan S, Burgos G, Liria R, Rodriguez F, Creed-Kanashiro H, Bonierbale M (2019) The Nutritional Contribution of Potato Varietal Diversity in Andean Food Systems: a Case Study. Am J Potato Res 96:151. https://doi.org/10.1007/s12230-018-09707-2

Dragsted LO, Krath B, Ravn-Haren G, Vogel UB, Vinggaard AM, Jensen PB, Loft S, Rasmussen SE, Sandstrom B, Pedersen A (2006) Biological effects of fruit and vegetables. Proc Nutr Soc 65:61-67

Duarte-Delgado D, Nústez-López C, Narváez-Cuenca C, Restrepo-Sánchez L, Melo S, Sarmiento F, Kushalappa A, Mosquera-Vásquez T (2016) Natural variation of sucrose, glucose and fructose contents in Colombian genotypes of Solanum tuberosum Group Phureja at harvest. J Sci Food Agric 96(12):4288-4294. https://doi.org/10.1002/jsfa.7783. Epub 2016 Jun 21

Duthie G, Duthie S, Kyle J (2000) Plant polyphenols in cancer and heart disease: implications as nutritional antioxidants. Nutr Res Rev 13:79-106

Ek KL, Brand-Miller J, Copeland L (2012) Glycaemic effect of potatoes. Food Chem 133:1230-1240

Englyst HN, Kingsman SM, Cummings JH (1992) Classification and measurement of nutritionally important starch fractions. Eur J Clin Nutr 46:S33-S50

Erdmann J, Hebeisen Y, Lippl F, Wagenpfeil S, Schusdziarra V (2007) Food intake and plasma ghrelin response during potato-, rice- and pasta-rich test meals. Eur J Clin Nutr 46:196-203

Ezekiel R, Singh N, Sharma S, Kaur A (2013) Beneficial phytochemicals in potato-a review. Food Res Int 50:487-496

FAO (2013) FAO statistical databases FAOSTAT. http://www.fao.org/faostat/en/\#data/FBS. Accessed October 12th 2017

FAO/OMS/UNU (2004) Human energy requirements. Report of joint FAO/WHO/UNU expert consultation. FAO, Rome

FAO/WHO (2001) Human vitamin and mineral requirements. Report of a joint FAO/WHO expert consultation. Bangkok, Thailand

Fernandes G, Velangi A, Wolever T (2005) Glycemic index of potatoes commonly consumed in North America. J Am Diet Assoc 105:557-562

Fernández-Garcia E, Carvajal-Lérida I, Pérez-Gálvez A (2009) In vitro bioaccessibility assessment as a prediction tool of nutritional efficiency. Nutr Res 29:751-760

Fernandez-Orozco R, Gallardo-Guerrero L, Hornero-Méndez D (2013) Carotenoid profiling in tubers of different potato (Solanum sp.) cultivars: accumulation of carotenoids mediated by xanthophyll esterification. Food Chem 141:2864-2872

Fiedor J, Burda K (2014) Potential role of carotenoids as antioxidants in human health and disease. Nutrients 6(2):466-488

Fitzpatrick TB, Basset GJ, Borel P, Carrari F, Della Penna D, Fraser PD, Hellmann H, Osorio S, Rothan C, Valpuesta V (2012) Vitamin deficiencies in humans: can plant science help? Plant Cell 24:395-414

La Frano M, de Moura F, Boy E, Lönnerdal B, Burri B (2014) Bioavailability of iron, zinc, and provitamin A carotenoids in biofortified staple crops. Nutr Rev 72(5):289-307. https://doi. org/10.1111/nure.12108.

Fossen T, Andersen $\varnothing$ (2000) Anthocyanins from tubers and shoots of the purple potato, Solanum tuberosum. J Hortic Sci Biotechnol 75(3):360-363. https://doi.org/10.1080/14620316.2000.1 1511251

Friedman M (1997) Chemistry, biochemistry, and dietary role of potato polyphenols. A review. J Agric Food Chem 45:1523-1540

Friedman M (2004) Analysis of biologically active compounds in potatoes (Solanum tuberosum), tomatoes (Lycopersicon esculentum), and jimson weed (Datura stramonium) seeds. J Chromatogr A 1054(1-2):143-155

Friedman M (2006) Potato glycoalkaloids and metabolites: roles in the plant and in the diet. J Agric Food Chem 54:8655-8681 
Friedman M (2015) Chemistry and anticarcinogenic mechanisms of glycoalkaloids produced by eggplants, potatoes, and tomatoes. J Agric Food Chem 63:3323-3337

Friedman M, McDonald G, Filadelfi-Keszi M. (1997) Potato glycoalkaloids: chemistry, analysis, safety, and plant physiology. Critical Reviews in Plant Sciences 16(1):55-132. https://doi. org/10.1080/07352689709701946

Friedman M, Roitman JN, Kozukue N (2003) Glycoalkaloid and calystegine contents of eight potato cultivars. J Agric Food Chem 51(10):2964-2973

Friedman M, Lee KR, Kim HJ, Lee IS, Kozukue N (2005) Anticarcinogenic effects of glycoalkaloids from potatoes against human cervical, liver, lymphoma, and stomach cancer cells. J Agric Food Chem 53:6162-6169

Fudge J, Mangel N, Gruissem W, Vanderschuren H, Fitzpatrick T (2017) Rationalising vitamin $\mathrm{B}_{6}$ biofortification in crop plants. Curr Opin Biotechnol 44:130-137. https://doi.org/10.1016/j. copbio.2016.12.004

Galliard T (1973) Lipids of potato tubers. I. Lipid and fatty acid composition of tubers from different varieties of potato. J Sci Food Agric 24(5):617-622

Gammone MA, Riccioni G, D’Orazio N (2015) Carotenoids: potential allies of cardiovascular health? Food Nutr Res 59:26762. https://doi.org/10.3402/fnr.v59.26762

Garcia-Alonso M, Pascual-Teresa S, Santos-Buelga C, Rivas-Gonzalo J (2004) Evaluation of the antioxidant properties of fruits. Food Chem 84:13-18

Garcia-Closas R, Berenguer A, Tormo MJ, Sanchez MJ, Quiros JR, Navarro C, Arnaud R, Dorronsoro M, Chirlaque MD, Barricarte A, Ardanaz E, Amian P, Martinez C, Agudo A, Gonzalez CA (2004) Dietary sources of vitamin C, vitamin E and specific carotenoids in Spain. Br J Nutr 91:1005-1011

Gibson S, Kurilich A (2013) The nutritional value of potatoes and potato products in the UK diet. Nutr Bull 38:389-399

Giusti MM, Polit MF, Ayvaz H, Tay D, Manrique I (2014) Characterization and quantitation of anthocyanins and other phenolics in native Andean potatoes. J Agric Food Chem 62:4408-4416

Habtemariam S, Lentini G (2015) The therapeutic potential of rutin for diabetes: an update. Mini Rev Med Chem 15(7):524-528

Han J, Kosukue N, Young K, Lee K, Friedman M (2004) Distribution of ascorbic acid in potato tubers and in home-processed and commercial potato foods. J Agric Food Chem 52(21):6516-6521

Hart D, Scott KJ (1995) Development and evaluation of an HPLC method for the analysis of carotenoids in foods and measurement of the carotenoid content of vegetables and fruits commonly consumed in the UK. Food Chem 54:101-111

Hashimoto N, Ito Y, Han KH, Shimada K, Sekkikawa M, Topping DL (2006) Potato pulps lowered the serum cholesterol and triglyceride levels in rats. J Nutr Sci Vitaminol 52:445-450

Hayashi K, Mori M, Matsunani Y, Suzutan T, Ogasawara M, Yoshida I, Hosokawa TA, Azuma M (2003) Anti Influenza Virus Activity of a Red-Fleshed Potato Anthocyanin. Food Sci Technol Res 9(3):242-244

Hayashi K, Hibasami H, Murakami T, Terahara N, Mori M, Tsukui A (2006) Induction of apoptosis in cultured human stomach cancer cells by potato anthocyanins and its inhibitory effects on growth of stomach cancer in mice. Food Sci Technol Res 12:22-26

Hellmann H, Mooney S (2010) Vitamin B6: A Molecule for Human Health? Molecules 15:442-459

Henry C, Lightowler H, Strik C, Storey M (2005) Glycaemic index values for commercially available potatoes in Great Britain. Br J Nutr 94(6):917-921

Holst B, Williamson G (2008) Nutrients and phytochemicals: from bioavailability to bioefficacy beyond antioxidants. Curr Opin Biotechnol 19:73-82

Hosseinian FS, Bea T (2007) Saskatoon and wild blueberries have higher antho-cyanin content than other Manitoba berries. J Agric Food Chem 55(26):10832-10838

Hu FB (2002) Dietary pattern analysis: a new direction in nutritional epidemiology. Curr Opin Lipidol 13(1):3-9

Ieri F, Innocenti M, Andrenelli L, Vecchio V, Mulinacci N (2011) Rapid HPLC/DAD/MS method to determine phenolic acids, glycoalkaloids and anthocyanins in pigmented potatoes (Solanum tuberosum L.) and correlations with variety and geographical origin. Food Chem 125:750-759 
Jiao J, Xu J-Y, Zhang W, Han S, Qin L-Q (2015) Effect of dietary fiber on circulating C-reactive protein in overweight and obese adults: a meta-analysis of randomized controlled trials. Int J Food Sci Nutr 66:114-119

Kanazawa T, Atsumi M, Mineo H, Fukushima M, Nishimura N, Noda T (2008) Ingestion of gelatinized potato starch containing a high level of phosphorus decreases serum and liver lipids in rats. J Oleo Sci 57:335-343

Kaspar KL, Park JS, Brown CR, Mathison BD, Navarre DA, Chew BP (2011) Pigmented potato consumption alters oxidative stress and inflammatory damage in men. J Nutr 141:108-111

Kenny OM, McCarthy CM, Brunton NP, Hossain MB, Rai DK, Collins SG, Jones PW, Maguire AR, O'Brien NM (2013) Anti-inflammatory properties of potato glycoalkaloids in stimulated Jurkat and Raw 264.7 mouse macrophages. Life Sci 92:775-782

Khachick F, Goli M, Beecher G, Holden J, Lusby W, Tenorio M, Barrera M (1992) Effect of food preparation on qualitative and quantitative distribution of major carotenoid constituents of tomatoes and several green vegetables. J Agric Food Chem 40:390-398

Khachik F, Cohen L, Zhao Z (1999) Metabolism of dietary carotenoidsand their possible role in prevention of cancer and macular de-generation. In: Shibamoto T, Terao J, Osawa T (eds) Functional foods for disease prevention I, American Chemical Society symposium series. Oxford University Press, New York, pp 71-85

Kimura M, Rodriguez-Amaya DB (2003) Carotenoid Composition of Hydroponic Leafy Vegetables. J Agric Food Chem 51:2603-2607. http://dx.doi.org/10.1021/jf020539b

King J, Slavin J (2013) White potatoes, human health, and dietary guidance. Adv Nutr 4:393S-401S. https://doi.org/10.3945/an.112.003525

Krinsky NI, Johnson EJ (2005) Carotenoid actions and their relation to health and disease. Mol Aspects Med 26(6):459-516. Review

Kubow S, Iskandar MM, Melgar-Bermudez E, Sleno L, Sabally K, Azadi B, How E, Prakash S, Burgos G, Felde TZ (2017) Effects of simulated human gastrointestinal digestion of two purple-fleshed potato cultivars on anthocyanin composition and cytotoxicity in colonic cancer and non-tumorigenic cells. Nutrients 9(9):pii: E953. https://doi.org/10.3390/nu9090953

Külen O, Stushnoff C, Holm DG (2012) Effect of cold storage on total phenolics content, antioxidant activity and vitamin C level of selected potato clones. J Sci Food Agric 93:2437-2444

Kumar D, Singh B, Parveen K (2004) An overview of the factors affecting sugar content of potatoes. Ann Appl Biol 145:247-256

Lachman J, Hamouz K (2005) Red and purple coloured potatoes as a significant antioxidant source in human nutrition - a review. Plant Soil Environ 51(11):477-482

Lachman J, Hamouz K, Orsak M, Pivec V (2001) Potato glycoalkaloids and their significance in plant protection and human nutrition - review. Rosstlinna Vyrova 47(4):181-191

Lachman J, Hamouz K, Sulc M, Orsak M, Pivec V, Hejtmankova A (2009) Cultivar differences of total anthocyanins and anthocyanidins in red and purple-fleshed potatoes and their relation to antioxidant activity. Food Chem 114:836-843

Lachman J, Hamouz K, Musilová J, Hejtmánková K, Kotíková Z, Pazderu K, Domkárová J, Pivec V, Cimr J (2013) Effect of peeling and three cooking methods on the content of selected phytochemicals in potato tubers with various colour of flesh. Food Chem 138:1189-1197

Lancaster J, Reay P, Norris J, Butler R (2000) Induction of flavonoids and phenolic acids in apple by UV-B and temperature. J Hortic Sci Biotechnol 75(2):142-148. https://doi.org/10.1080/14 620316.2000 .11511213

Langner E, Rzeski W, Kaczor J, Kandefer-Szersze M, Pierzynowski SG (2009) Tumour cell growth-inhibiting properties of water extract isolated from heated potato fibre (Potex). J PreClin Clin Res 3:36-41

Larsson SC, Wolk A (2016) Potato consumption and risk of cardiovascular disease: 2 prospective cohort studies. Am J Clin Nutr 104:1245-1252

Lee KR, Kozukue N, Han JS, Park JH, Chang EY, Baek EJ, Chang JS, Friedman M (2004) Glycoalkaloids and metabolites inhibit the growth of human colon (HT29) and liver (HepG2) cancer cells. J Agric Food Chem 52:2832-2839 
Leeman M, Östman E, Björck I (2005) Vinegar dressing and cold storage of potatoes lowers postprandial glycaemic and insulinaemic responses in healthy subjects. Eur J Clin Nutr 59:1266-1271

Liang N, Kitts D (2015) Role of chlorogenic acids in controlling oxidative and inflammatory stress conditions. Nutrients 8(1). https://doi.org/10.3390/nu8010016

Lin BW, Gong CC, Song HF, Cui YY (2017) Effects of anthocyanins on the prevention and treatment of cancer. Br J Pharmacol 174:1226-1243

Liu Q, Tarn R, Lynch D, Skjodt N (2007) Physicochemical properties of dry matter and starch from potatoes grown in Canada. Food Chem 105:897-907

Liyanage R, Han KH, Watanabe S, Shimada K, Sekikawa M, Ohba K (2008) Potato and soy peptide diets modulate lipid metabolism in rats. Biosci Biotechnol Biochem 72:943-950

Liyanage R, Han KH, Shimada KI, Sekikawa M, Tokuji Y, Ohba K (2009) Potato and soy peptides alter caecal fermentation and reduce serum non-HDL cholesterol in rats fed cholesterol. Eur J Lipid Sci Technol 111:884-892

Lockyer S, Spiro A, Stanner S (2016) Dietary fibre and the prevention of chronic disease-should health professionals be doing more to raise awareness? Nutr Bull 41:214-231

Lombardo S, Pandino G, Mauromicale G (2013) The influence of growing environment on the antioxidant and mineral content of "early" crop potato. J Food Compos Anal 32(1):28-35

Lovat C, Nassar A, Kubow S, Li X, Donnelly D (2016) Metabolic biosynthesis of potato (Solanum tuberosum L.) antioxidants and implications for human health. Crit Rev Food Sci Nutr 56(14):2278-2303

Love SL, Pavek JJ (2008) Positioning the potato as a primary food source of vitamin C. Am J Potato Res 85:277-285

Lv C, Kong H, Dong G, Liu L, Tong K, Sun H, Chen B, Zhang C, Zhou M (2014) Antitumor efficacy of $\alpha$-solanine against pancreatic cancer in vitro and in vivo. PLoS One 9(2):e87868

Lynch DR, Liu Q, Tarn TR, Bizimungu B, Chen Q, Harris P, Chik CL, Skjodt NM (2007) Glycemic index: a review and implications for the potato industry. Am J Potato Res 84:179-190

Madiwale GP, Reddivari L, Holm DG, Vanamala J (2011) Storage elevates phenolic content and antioxidant activity but suppresses antiproliferative and pro-apoptotic properties of coloredflesh potatoes against human colon cancer cell lines. J Agric Food Chem 59:8155-8166

Makinen S, Kelloniemi J, Pihlanto A, Makinen K, Korhonen H, Hopia A (2008) Inhibition of angiotensin converting enzyme I caused by autolysis of potato proteins by enzymatic activities confined to different parts of the potato tuber. J Agric Food Chem 56:9875-9883

Mattila P, Hellstrom J (2006) Phenolic acids in potatoes, vegetables, and some of their products. J Food Compos Anal 20:152-160

McGill C, Kurilich A, Davignon J (2013) The role of potatoes and potato components in cardiometabolic health: a review. J Ann Med 45(7):467-473

Miao M, Jiang B, Cui S, Zhang T, Jin Z (2015) Slowly digestible starch-a review. Crit Rev Food Sci Nutr 55(12):1642-1657. https://doi.org/10.1080/10408398.2012.704434

Miller R, Stanner S (2016) Baked, mashed, boiled or fried—can potatoes increase the risk of hypertension? Nutr Bull 41:252-256

Mills CE, Tzounis X, Oruna-Concha MJ, Mottram DS, Gibson GR, Spencer JP (2015) In vitro colonic metabolism of coffee and chlorogenic acid results in selective changes in human faecal microbiota growth. Br J Nutr 113:1220-1227

Mínguez Mosquera M, Hornero-Méndez D (1994) Comparative Study of the Effect of Paprika Processing on the Carotenoids in Peppers (Capsicum annuum) of the Bola and Agridulce Varieties. J Agric Food Chem 42(7):1555-1560

Monro J, Mishra S, Blandford E, Anderson J, Genet R (2009) Potato genotype differences in nutritionally distinct starch fractions after cooking, and cooking plus storing cool. J Food Compos Anal 22(6):539-545

Moonney S, Chen L, Kuhn C, Navarre R, Knowles NR, Hellman H (2013) Genotype-specific changes in vitamin $\mathrm{B}_{6}$ content and the PDX family in potato. Bio Med Res Int. Article ID 389723, 7 pages. https://doi.org/10.1155/2013/389723 
Müller HZ (1997) Determination of the carotenoid content in selected vegetables and fruit by HPLC and photodiode array detection. Lebensm Unters Forsch 204:88. https://doi.org/10.1007/ s002170050042

Muraki I, Rimm EB, Willett WC, Manson JE, Hu FB, Sun Q (2016) Potato consumption and risk of type 2 diabetes: results from three prospective cohort studies. Diabetes Care 39(3):376-384. https://doi.org/10.2337/dc15-0547

Muttucumaru N, Elmore J, Curtis T, Mottram D, Parry M, Halford N (2008) Reducing acrylamide precursors in raw materials derived from wheat and potato. J Agric Food Chem 56(15):61676172. https://doi.org/10.1021/jf800279d. Epub 2008 Jul 15

Naidu K (2003) Vitamin C in human health and disease is still a mystery? An overview. Nutr J 2:7

Nassar AM, Sabally K, Kubow S, Leclerc YN, Donnelly DJ (2012) Some Canadian-grown potato cultivars contribute to a substantial content of essential dietary minerals. J Agric Food Chem 60(18):4688-4696. https://doi.org/10.1021/jf204940t

Natella F, Nardini M, Belelli F, Scaccini C (2007) Coffee drinking induces incorporation of phenolic acids into LDL and increases the resistance of LDL to ex vivo oxidation in humans. Am J Clin Nutr 86:604-609

Navarre DA, Shakya R, Holden J, Kumar S (2010) The effect of different cooking methods on phenolics and vitamin $\mathrm{C}$ in developmentally young potato tubers. Am J Potato Res 87(4):350-359

Neilson J, Lagüe M, Thomson S, Aurousseau F, Murphy AM, Bizimungu B, Deveaux V, Bègue Y, JME J, Tai HH (2017) Gene expression profiles predictive of cold-induced sweetening in potato. Funct Integr Genomics 17(4):459-476

Niu K, Momma H, Kobayashi Y, Guan L, Chujo M, Otomo A, Ouchi E, Nagatomi R (2016) The traditional Japanese dietary pattern and longitudinal changes in cardiovascular disease risk factors in apparently healthy Japanese adults. Eur J Nutr 55:267-279

Ombra M, Fratianni F, Granese T, Cardinale F, Cozzolino A, Nazzaro F (2015) In vitro antioxidant, antimicrobial and anti-proliferative activities of purple potato extracts (Solanum tuberosum cv Vitelotte noire) following simulated gastro-intestinal digestion. Nat Prod Res 29(11):10871091. https://doi.org/10.1080/14786419.2014.981183

Olthof MR, Hollman PC, Buijsman MN, van Amelsvoort JM, Katan MB (2003) Chlorogenic acid, quercetin-3-rutinoside and black tea phenols are extensively metabolized in humans. J Nutr 133:1806-1814

Otten J, Hellwig P, Meyers L (2010) Dietary reference intakes: the essential guide to nutrient requirements. The National Academies Press, Washington, DC

Pascual-Teresa S, Sanchez-Ballesta MT (2008) Anthocyanins: from plant to health. Phytochem Rev 7:281-299

Pastorino S, Richards M, Pierce M, Ambrosini GL (2016) A high-fat, high-glycaemic index, lowfibre dietary pattern is prospectively associated with type 2 diabetes in a British birth cohort. Br J Nutr 115:1632-1642

Piñeros-Niño C, Narváez-Cuenca C, Kushalappa A, Mosquera T (2017) Hydroxycinnamic acids in cooked potato tubers from Solanum tuberosum group Phureja. Food Sci Nutr 5(3):380-389

Puchau B, Zulet MA, Gonzalez de Echavarri A, Hermsdorff HH, Martinez JA (2010) Dietary total antioxidant capacity is negatively associated with some metabolic syndrome features in healthy young adults. Nutrition 26(5):534-541

Raigond P, Ezekiel R, Raigond B (2014) Resistant starch in food. J Sci Food Agric 95(10):19681978. https://doi.org/10.1002/jsfa.6966. Review

Ramadan M, Oraby H (2016) Fatty acids and bioactive lipids of potato cultivars: an overview. J Oleo Sci 65(6):459-470. https://doi.org/10.5650/jos.ess 16015

Rautiainen S, Serafini M, Morgenstern R, Prior RL, Wolk A (2008) The validity and reproducibility of food-frequency questionnaire-based total antioxidant capacity estimates in Swedish women. Am J Clin Nutr 87:1247-1253

Reddivari L, Hale AL, Miller JC (2007a) Determination of phenolic content, composition and their contribution to antioxidant activity in specialty potato selections. Am J Potato Res 84:275-282

Reddivari L, Vanamala J, Chintharlapalli S, Safe SH, Miller J (2007b) Anthocyanin fraction from potato extracts is cytotoxic to prostate cancer cells through activation of caspase-dependent and caspase-independent pathways. Carcinogenesis 28(10):2227-2235 
Reddivari L, Vanamala J, Safe SH, Miller JC (2010) The bioactive compounds $\alpha$-chaconine and gallic acid in potato extracts decrease survival and induce apoptosis in $\mathrm{LNCaP}$ and $\mathrm{PC} 3$ prostate cancer cells. Nutr Cancer 62:601-610

Reyes LF, Miller JC, Cisneros-Zevallos L (2005) Antioxidant capacity, anthocyanins and total phenolics in purple- and red-fleshed potato (Solanum tuberosum L.) genotypes. Am J Potato Res 82:271-277

Richelle M, Tavazzi I, Offord E (2001) Comparison of antioxidant activity of commonly consumed polyphenolic beverages (coffee, cocoa, tea) prepared per cup serving. J Agric Food Chem 49:3438-3442

Robert L, Narcy A, Rock E, Demigne C, Mazur A, Rémésy C (2006) Entire potato consumption improves lipid metabolism and antioxidant status in cholesterol-fed rat. Eur J Nutr 45:267-274

Roberts SB (2000) High-glycemic index foods, hunger, and obesity: is there a connection? Nutr Rev 58:163-169

Rodríguez B, Ríos D, Rodríguez E, Díaz C (2010) Influence of the cultivar on the organic acid and sugar composition of potatoes. J Sci Food Agric 90(13):2301-2309. https://doi.org/10.1002/ jsfa.4086

Rodriguez-Amaya DB (2015) Status of carotenoid analytical methods and in vitro assays for the assessment of food quality and health effects. Curr Opin Food Sci 1:56-63. https://doi. org/10.1016/j.cofs.2014.11.005

Ruprich J, Rehurkova I, Boon PE, Svensson K, Moussavian S, Van der Voet H, Bosgra S, Van Klaveren JD, Busk L (2009) Probabilistic modeling of exposure doses and implications for health risk characterization: glycoalkaloids from potatoes. Food Chem Toxicol 47:2899-2905

Sajilata MG, Singhal RS, Kulkarni PR (2006) Resistant starch—a review. Compr Rev Food Sci Food Saf 5:1-17

Salmeron J, Manson JE, Stampfer MJ, Colditz GA, Wing AL, Willett WC (1997) Dietary fiber, glycemic load, and risk of non-insulin-dependent diabetes mellitus in women. J Am Med Assoc 277:472-477

Slavin JL (2008) Position of the American Dietetic Association: health implications of dietary fiber. J Am Diet Assoc 108:1716-1731

Soh NL, Brand-Miller J (1999) The glycaemic index of potatoes: the effect of variety, cooking method and maturity. Eur J Clin Nutr 53:249-254

Spanos GA, Wrolstad RE (1992) Phenolics of apple, pear, and white grape juices and their changes with processing and storage. A review. J Agric Food Chem 40:1478-1487

Spinneker A, Sola R, Lemmen V, Castillo MJ, Pietrzik K, González-Gross M (2007) Vitamin B 6 status, deficiency and its consequences-an overview. Nutr Hosp 22(1):7-24

Stalmach A, Steiling H, Williamson G, Crozier A (2010) Bioavailability of chlorogenic acids following acute ingestion of coffee by humans with an ileostomy. Arch Biochem Biophys 501:98-105

Sun H, Lv C, Yang L, Wang Y, Zhang Q, Yu S, Kong H, Wang M, Xie J, Zhang C, Zhou M (2014) Solanine induces mitochondria-mediated apoptosis in human pancreatic cancer cells. BioMed Res Int 2014:805926

Tajner-Czopek M, Jarych-Szyszka M, Lisińska G (2008) Changes in glycoalkaloids content of potatoes destined for consumption. Food Chem 106(2):706-711

Tee E, Lim C (1991) Carotenoid composition and content of Malaysian vegetables and fruits by the AOAC and HPLC methods. Food Chem 41:309-339

Teucher B, Olivares M, Cori H (2004) Enhancers of iron absorption: ascorbic acid and other organic acids. Int J Vitam Nutr Res. 74(6):403-419

Tian J, Chen C, Ye X, Chen S (2016) Health benefits of the potato affected by domestic cooking: a review. Food Chem 202:165-175

Tomas-Barberan F, García-Villalba R, Quartieri A, Raimondi S, Amaretti A, Leonardi A, Rossi M (2014) In vitro transformation of chlorogenic acid by human gut microbiota. Mol Nutr Food Res 58(5):1122-1131. https://doi.org/10.1002/mnfr.201300441. Epub 2013 Dec 23

van Het Hof KH, West CE, Weststrate JA, Hautvast JG (2000) Dietary factors that affect the bioavailability of carotenoids. J Nutr 130(3):503-506 
Vaziri ND, Liu SM, Lau WL, Khazaeli M, Nazertehrani S, Farzaneh SH, Kieffer DA, Adams SH, Martin RJ (2014) High amylose resistant starch diet ameliorates oxidative stress, inflammation, and progression of chronic kidney disease. PloS One 9:e114881

Venn B, Green T (2007) Glycemic index and glycemic load: measurement issues and their effect on diet-disease relationships. Eur J Clin Nutr 61(Suppl 1):S122-S131

Veronese N, Stubbs B, Noale M, Solmi M, Vaona A, Demurtas J, Nicetto D, Crepaldi G, Schofield P, Koyanagi A, Maggi S, Fontana L (2017) Fried potato consumption is associated with elevated mortality: an 8-y longitudinal cohort study. Am J Clin Nutr 106:162-167

Vinson J, Demkosky C, Navarre D, Smyda M (2012) High-antioxidant potatoes: acute in vivo antioxidant source and hypotensive agent in humans after supplementation to hypertensive subjects. J Agric Food Chem 60(27):6749-6754. https://doi.org/10.1021/jf2045262

Visvanathan R, Jayathilake C, Chaminda Jayawardana B, Liyanage R (2016) Health-beneficial properties of potato and compounds of interest. J Sci Food Agric 96(15):4850-4860. https:// doi.org/10.1002/jsfa.7848. Epub 2016 Jul 7. Review

Wada L, Ou B (2002) Antioxidant activity and phenolic content of Oregon cane-berries. J Agric Food Chem 50(12):3495-3500

Wahyuni Y, Ballester A, Sudarmonowati E, Bino RJ, Bovy AG (2011) Metabolite biodiversity in pepper (Capsicum) fruits of thirty-two diverse accessions: variation in health-related compounds and implications for breeding. Phytochemistry 72(11-12):1358-1370

Wang Q, Chen Q, He M, Mir P, Su J, Yang Q (2011) Inhibitory effect of antioxidant extracts from various potatoes on the proliferation of human colon and liver cancer cells. Nutr Cancer 63:1044-1052

Wang S, Copeland L, Brand-Miller J (2014) Discovery of a low-glycaemic index potato and relationship with starch digestion in vitro. Br J Nutr 111(4):699-705. https://doi.org/10.1017/ S0007114513003048

Wang W, Sun C, Mao L, Ma P, Liu F, Yang J, Gao Y (2016) The biological activities, chemical stability, metabolism and delivery systems of quercetin: a review. Trends Food Sci Technol 56:21-38

WHO (World Health Organization) (2012) Guideline: potassium intake for adults and children. World Health Organization, Geneva

Winkel-Shirley B (2001) Flavonoid biosynthesis. A colorful model for genetics, biochemistry, cell biology, and biotechnology. Plant Physiol 126:485-493

Woolfe J, Poats S (1987) The Potato in the Human Diet. Cambridge University Press. 0521326699, 9780521326698

Wu X, Beecher GR, Holden JM, Haytowitz DB, Gebhardt SE, Prior RL (2006) Concentration of anthocyanins in common foods in the United States and estimation of normal consumption. J Agric Food Chem 54(11):4069-4075

Wu J, Cho E, Willett WC, Sastry SM, Schaumberg DA (2015) Intakes of lutein, zeaxanthin, and other carotenoids and age-related macular degeneration during 2 decades of prospective follow-up. JAMA Ophthalmol 133(12):1415-1424. https://doi.org/10.1001/jamaophthalmol.2015.3590

Yang SA, Paek SH, Kozukue N, Lee KR, Kim JA (2006) Alpha-chaconine, a potato glycoalkaloid, induces apoptosis of HT-29 human colon cancer cells through caspase-3 activation and inhibition of ERK 1/2 phosphorylation. Food Chem Toxicol 44:839-846

Yogendra KN, Kushalappa AC, Sarmiento F, Rodriguez E, Mosquera T (2015) Metabolomics deciphers quantitative resistance mechanisms in diploid potato clones against late blight. Funct Plant Biol 42:284-298

Yuan G, Sun B, Yuan J, Wang Q (2009) Effects of different cooking methods on health-promoting compounds of broccoli. J Zhejiang Univ Sci B 10(8):580-588. https://doi.org/10.1631/jzus. B0920051

Zeeman SC, Kossmann J, Smith AM (2010) Starch: its metabolism, evolution, and biotechnological modification in plants. Annu Rev Plant Biol 61:209-234

Zeng C (2013) Effects of different cooking methods on the vitamin C content of selected vegetables. Nutr Food Sci 43(5):438-443. https://doi.org/10.1108/NFS-11-2012-0123 
Open Access This chapter is licensed under the terms of the Creative Commons Attribution 4.0 International License (http://creativecommons.org/licenses/by/4.0/), which permits use, sharing, adaptation, distribution and reproduction in any medium or format, as long as you give appropriate credit to the original author(s) and the source, provide a link to the Creative Commons license and indicate if changes were made.

The images or other third party material in this chapter are included in the chapter's Creative Commons license, unless indicated otherwise in a credit line to the material. If material is not included in the chapter's Creative Commons license and your intended use is not permitted by statutory regulation or exceeds the permitted use, you will need to obtain permission directly from the copyright holder. 